\title{
CARTÓRIOS JUDICIAIS E O ACESSO À JUSTIÇA: TENSÕES E DISPUTAS.
}

\author{
Dissertação de Mestrado
}

Orientador: Professor Doutor Guilherme Assis de Almeida (FD - USP)

Co-orientadora: Professora Doutora Ana Lúcia Pastore Schritzmeyer (FFLCH - USP)

UNIVERSIDADE DE SÃO PAULO

FACULDADE DE DIREITO

SÃO PAULO - SP 



\title{
CARTÓRIOS JUDICIAIS E O ACESSO À JUSTIÇA: TENSÕES E DISPUTAS.
}

\author{
Dissertação de Mestrado apresentada à Banca \\ Examinadora do Programa de Pós-Graduação da \\ Faculdade de Direito da Universidade de São Paulo, na \\ área de concentração em Direitos Humanos, sob a \\ orientação do Professor Doutor Guilherme Assis de \\ Almeida e Co-orientação da Professora Doutora Ana \\ Lúcia Pastore Schritzmeyer.
}

UNIVERSIDADE DE SÃO PAULO

FACULDADE DE DIREITO

SÃO PAULO - SP 
Autorizo a reprodução e divulgação total ou parcial deste trabalho, por qualquer meio convencional ou eletrônico, para fins de estudo e pesquisa, desde que citada a fonte.

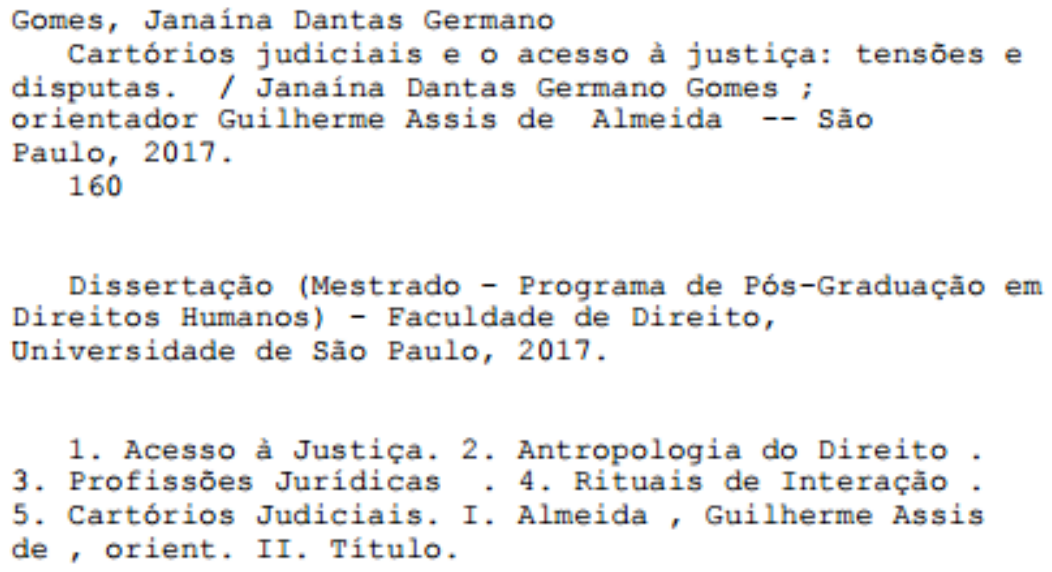


GOMES, Janaína Dantas Germano. Cartórios judiciais e o acesso à justiça: tensões e disputas. Dissertação de Mestrado apresentada à Faculdade de Direito da Universidade de São Paulo, como requisito parcial para obtenção do título de Mestre em Direito.

Aprovado em: 1

Banca examinadora

Prof. Dr. Instituição:

Julgamento: Assinatura:

Prof. Dr. Instituição:

Julgamento: Assinatura:

Prof. Dr. Instituição:

Julgamento: Assinatura:

Prof. Dr. Instituição:

Julgamento: Assinatura:

Prof. Dr. Instituição:

Julgamento: Assinatura:

Prof. Dr. Instituição:

Julgamento: Assinatura: 



\section{Agradecimentos}

Agradeço meus pais, Antonio Carlos e Josete, e meu irmão Otávio, tão queridos, pelo apoio na empreitada de mudar de cidade, dedicar-me ao mestrado, e trilhar o caminho profissional e pessoal que escolhi.

Agradeço a querida Ana Lúcia Pastore Schritzmeyer que com seu acolhimento e carinho imensos co-orientou esta pesquisa e é também orientadora de projetos de vida para mim e minhas colegas queridas do Núcleo Antropologia do Direito - NADIR.

Foi por meio do NADIR, e de Ana, que conheci Guilherme Assis de Almeida, que me concedeu a oportunidade de realizar o mestrado na Faculdade de Direito, sempre depositando imensa confiança em mim e em meu trabalho como pesquisadora e profissional da área de Diretos Humanos. Guilherme, obrigada pelo apoio fundamental ao longo destes anos.

Agradeço também a todas as pessoas queridas que me incentivaram, ouviram pacientemente todas as angústias desse processo de pesquisa, leram papers, debateram textos em cafés e congressos, e me ajudaram a conhecer os escreventes e operadores do direito que se tornaram meus interlocutores nesta pesquisa e a percorrer os caminhos desta pesquisa até a presente dissertação.

Um agradecimento especial para as lindas e queridas do NADIR, da Clínica de Direitos Humanos Luiz Gama - tantas e tão amadas! E um agradecimento que vai além do auxílio no mestrado, mas também na vida, às amigas e amigos de todas as horas Amanda Camargo, Juliane Yamakawa, Thá Marcussi, Thá Tiriba, Camila Nicácio, Renato, Luís Renato Vedovato.

Destaco o apoio e carinho da minha família em Campinas, em que tios e tias inseridos no mundo do Direito e da pesquisa me forneceram dicas e contatos preciosos para a realização desta pesquisa.

Agradeço ainda Alexandre Santos Cunha e Bernardo Medeiros do IPEA por me selecionarem para uma equipe de pesquisa de excelência que me permitiu conhecer muitos interlocutores e realidades cartoriais do estado de São Paulo e ao Daniel De Lucca pelas trocas importantes, sugestões e empréstimo de muitos livros para a realização do trabalho e escrita final. 

Ainda, este trabalho só foi possível em razão da confiança de cada um de meus interlocutores, advogados e advogadas, escreventes, diretores e diretoras de cartórios, magistrados e magistradas - neste texto registrados com siglas em razão do anonimato que lhes prometi - e que concederam seu tempo e sua confiança para a construção desta pesquisa. Agradeço a vocês por compartilharem comigo questões tão importantes de suas vidas, seus trabalhos e formas de ver o mundo. Essa narrativa que construí é feita com imenso afeto e respeito por vocês e suas histórias. 

GOMES, Janaína Dantas Germano. Cartórios judiciais e o acesso à justiça: tensões e disputas. Dissertação (Mestrado) Faculdade de Direito da Universidade de São Paulo, 2017.

RESUMO: O trabalho ora apresentado é fruto de uma pesquisa de caráter interdisciplinar que busca descrever e analisar as relações entre escreventes e advogados em balcões de fóruns da cidade de São Paulo e perquirir sua relação com o acesso à justiça. A metodologia utilizada foi a qualitativa. A partir de uma perspectiva etnográfica, cara à antropologia, buscou-se perseguir o conflito, as tensões e disputas, vivenciadas nos balcões de atendimento, amparando-se especialmente na etnografia multi-situada. Para refletir sobre o acesso à justiça e os balcões judiciais foi realizado um levantamento bibliográfico interessado, na primeira parte da dissertação. $\mathrm{O}$ acesso à justiça, entendido como o acesso também a uma esfera da cidadania está presente nos balcões, sendo realizado cotidianamente pelos profissionais que neles interagem. As interações entre escreventes e advogados foram descritas na segunda parte do texto. O aprendizado, as formas de vestir-se e comportar-se e o entendimento da burocracia judicial como uma linha de montagem foram explorados à luz dos conceitos de Erving Goffman e do entendimento deste espaço como de interações rituais. A análise das interações concentra-se na terceira parte do trabalho. Por fim, conclui-se pelo reforço de estruturas de hierarquia e autoridade no espaço dos balcões, inerentes à estrutura do judiciário. As narrativas dos escreventes guiam à uma sensação de invisibilidade dentro da estrutura que gera adoecimentos, bem como, por parte dos advogados, o desencantamento com a estrutura e o crescente desenvolvimento de estratégias que não visam a melhora das estruturas mas, sim, a resolução de questões pontuais nos balcões. O diálogo e a reforma das relações nas estruturas do poder judiciário são, por fim, apontados como possíveis caminhos para novos rearranjos nesta estrutura sujeita a constantes reformas que pouco têm avançado na modernização das relações das pessoas dentro das estruturas burocráticas.

Palavras Chave: Acesso à Justiça, Antropologia do Direito, Profissões Jurídicas, Rituais de Interação - Cartórios Judiciais 

GOMES, Janaína Dantas Germano. Court offices and access to justice: tensions and struggles. Dissertation (Master) Faculty of Law, University of São Paulo, 2017.

ABSTRACT: This dissertation is the result of an interdisciplinary research which aimed to discuss the interaction between lawyers and court officers in some courts in the city of São Paulo and discuss its relation to the right of access to justice. From an ethnographic perspective, cherished by Anthropology, it was aimed to pursue the conflict, the tensions and disputes with the support of a multi-sited ethnography. To promote the dialogue between the access to justice and the judicial bureaucracy, an effort to compilate texts was made. The access to justice was also understood as an access to a certain sphere of citizenship, realized by the everyday interactions of the professionals of law. The interactions between lawyers and court officers were discussed on part two of the essay. What court officers and lawyers have to learn, how to behave and interact, and how they claimed the courts were manufacturing decisions, as if in a production line, were analyzed within concept of Erving Goffman and his rituals of interaction. Finally, the interactions were analyzed in part three. The conclusions of this dissertation guide us for the presence of deep relation of hierarchy and authority on the courts, inherent to the structure of the judicial power. The discussions made by court officers guide us to a feeling of invisibility and social humiliation inside the court, which leads to illnesses. Lawyers live the disenchantment with the structure and the crescent development of strategies that do not aim to the transformation of the structure, but solely the resolution of their own problems. The negotiations and the transformation of human relations in such structure are pointed out as some of the ways to make some advances in the modernization of law practices.

Key Words: Acess to Justice - Anthropology of Law - Legal Professions - Rituals of interaction - Court Offices 



\section{SUMÁRIO}

INTRODUÇÃO E CONSIDERAÇÕES METODOLÓGICAS .........................................11

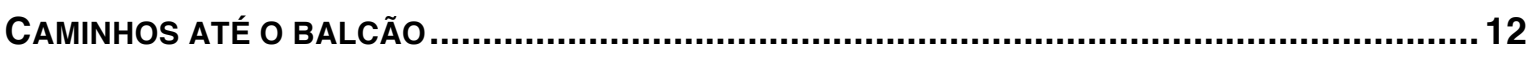

A ANTROPOLOGIA E O DIÁLOGO COM AS PESQUISAS JURÍDICAS ........................................... 15

MATERIAIS ANALISADOS: CONHECENDO E ENTREVISTANDO MEUS INTERLOCUTORES .............18

PARTE I: CARTÓRIOS JUDICIAIS E O ACESSO À JUSTIÇA. .................................. 25

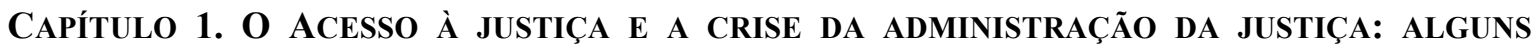
ENTENDIMENTOS ATÉ O BALCÃO.................................................................................................25

1.1 CIDADANIA E O ACESSO À JUSTIÇA.................................................................................................30

CAPÍTULO 2. CARTÓRIOS JUDICIAIS ...............................................................................................36

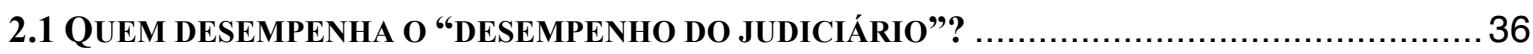

2.2 O QUE É UM FÓRUM, O QUE É UM CARTÓRIO: A ORGANIZAÇÃo JUDICIÁRIA.......................43

2.3 ALgUMAS LEgISLAÇõeS APLICÁVEIS AO ATENDIMENTO NOS BALCÕES. ......................... 49

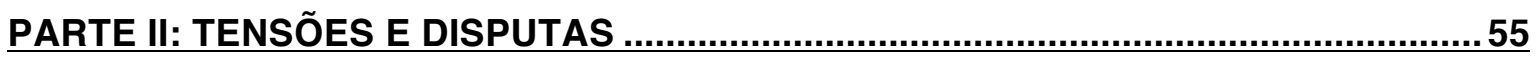

CAPÍtULO 3. RITUAIS DE INTERAÇÃo E OS BALCÕES JUdICIAIS ........................................55

3.1 RITUAIS: CAMINHOS ATÉ UMA CONCEITUAÇÃo POSSÍVEL NOS BALCÕES. ........................56

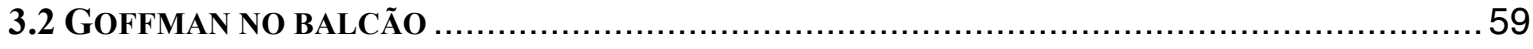

3.3 VIDA DE CARTÓRIO, VIDA DE ADVOGADO: INTERAGINDO NOS BALCÕES.........................61

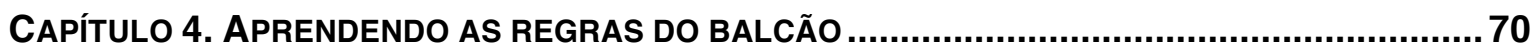

4.1 ADVOGADOS, ESTAGIÁRIOS E OS BALCÕES - JUVENTUDE E INEXPERIÊNCIA .....................70

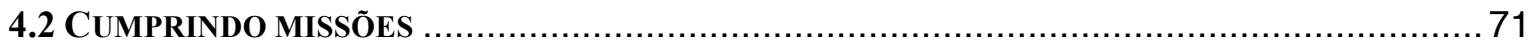

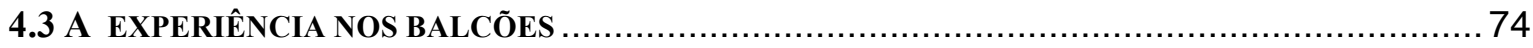

4.3 SEGREDOS DO GRUPO: APRENDENDO COMO AS COISAS FUNCIONAM EM CADA CARTÓRIO.79

4.4 “SEMPRE TEM ALGUÉM QUE CARREGA O CARTÓRIO NAS COSTAS" ................................ 81

4.5 CONSTRUINDO A FACHADA: “NINGUÉM CHEGA AQUI ODIANDO O BALCÃO”..................... 83

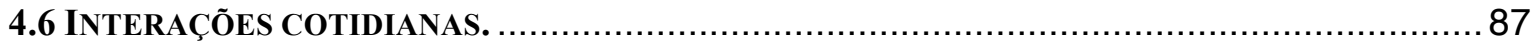

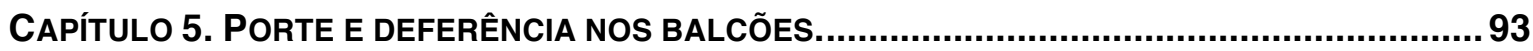

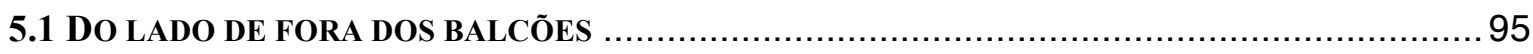

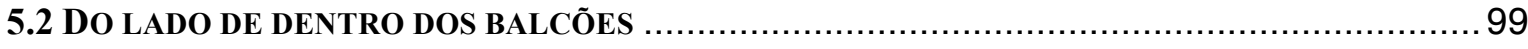

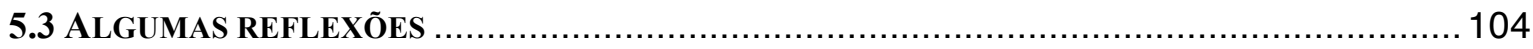

CAPÍTULO 6. A LINHA dE PROdUÇÃo E SUAS FORMAS dE PRESSÃO.....................................107

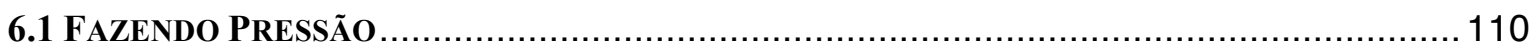





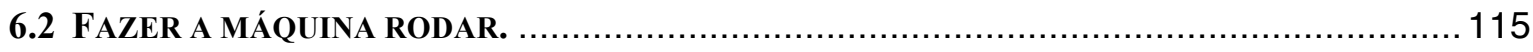

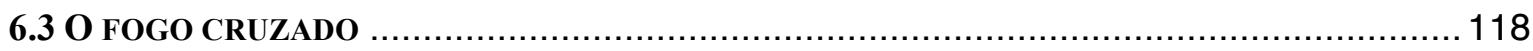

PARTE III: (IN)VISIBILIDADES, EMOÇÕES, JEITINHOS E SABERES LOCAIS. .......121

CAPÍtUlo 7. Algumas INTERPRETAÇões A PARTIR doS BALCÕES ....................................121

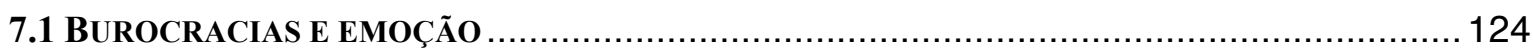

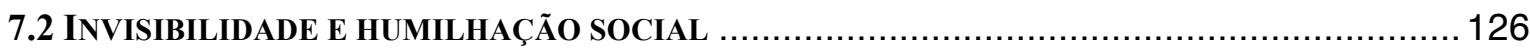

7.3 ENTRE O “JEITINHO” E O “VOCÊ SABE COM QUEM ESTÁ FALANDO?”............................ 129

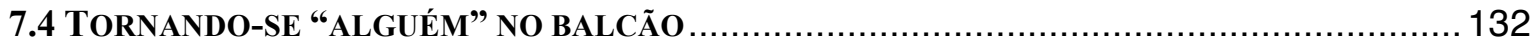

7.5 O JUDICIÁRIO É UMA MÁQUINA DE JUSTIÇA, E A MÁQUINA ESTÁ EMPERRADA................. 133

CONSIDERAÇÕES FINAIS:

REFERÊNCIAS BIBLIOGRÁFICAS:

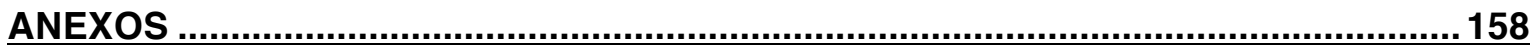

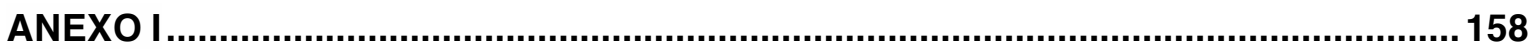

LISTA DE PRÉdIOS ADMINISTRATIVOS E FÓRUNS DA CIDADE DE SÃo PAULO SEGUNDO O SITE dO TRIBUNAL DE JUSTIÇA, EM DEZEMBRO DE 2016.......................................................... 158

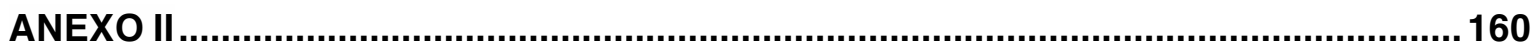

NORMATIVAS QUE TRATAM ESPECIFICAMENTE DO ACESSO DE ADVOGADOS E ADVOGADAS AOS FÓRUNS E PROCESSOS: 


\section{INTRODUÇÃO E CONSIDERAÇÕES METODOLÓGICAS}

O presente texto é o produto final de minha pesquisa de mestrado na Faculdade de Direito do Largo São Francisco - USP, orientada pelo professor Guilherme Assis de Almeida (DFD-FD-USP) e co-orientada pela professora Ana Lúcia Pastore Schritzmeyer (DAFFLCH-USP), área de concentração em Direitos Humanos. Investigo as interações entre advogados e escreventes nos balcões dos cartórios judiciais, buscando pensar qual sua relação com o direito fundamental do acesso à justiça. A dissertação foi dividida em três partes, que apresento a seguir.

A primeira parte, "Cartórios Judiciais e Acesso à Justiça", trata deste direito fundamental e sua relação com os cartórios judiciais. Apresento um panorama dos materiais produzidos até o momento sobre estes espaços de trabalho da burocracia judiciária, destacando o protagonismo da figura do magistrado e dos conceitos de produtividade e eficiência na maior parte das pesquisas, e a baixa incidência de trabalhos sobre os escreventes e sua relação com o acesso à justiça. De modo geral, aponta-se a necessidade de estudo do cotidiano dos cartórios e do ofício dos escreventes judiciais, a influência de aspectos interpessoais nas rotinas de trabalho e a insatisfação com a gestão de pessoas dentro dos tribunais de justiça.

A segunda parte, "Tensões e Disputas" apresenta alguns elementos que se destacaram nas narrativas coletadas ao longo do período de pesquisa em campo. $\mathrm{O}$ aprendizado nos espaços dos cartórios, o modo de se vestir e de pressionar a máquina de justiça foram descritos à luz da produção de Erving Goffman sobre as interações sociais. Ainda, o conceito de ritual é apresentado como aplicável à essa realidade, em que interações cotidianas atualizam e reforçam conteúdos compartilhados simbolicamente nos fóruns pelos profissionais do direito e escreventes.

Na terceira e última parte deste trabalho, “(In)visibilidades, Emoções, Jeitinhos e Saberes Locais", analisei as interações entre as pessoas nos balcões a partir deste posto de observação, apreciando os materiais coletados em diálogo, especialmente, com o ensaio sobre a expressão "Você sabe com quem está falando?” de Roberto da Matta (1997).

Passo assim, a descrever os caminhos que percorri para o desenvolvimento desta pesquisa e este produto final. 


\section{Caminhos até o balcão}

O dia a dia dos cartórios judiciais, mais especificamente o trabalho em seus balcões de atendimento, costuma ser restrito àqueles que os frequentam como advogados, estagiários e escreventes. Como se dá o atendimento, o que está em jogo? O que pedem os advogados, como respondem os cartorários? Existe alguma relação possível entre as interações e o direito fundamental do acesso à justiça, previsto na Constituição Federal de 1988 ?

O foco deste trabalho é o encontro entre profissionais do direito, bacharéis formados e em formação, e escreventes técnicos judiciários e seus estagiários. As estratégias, performances e argumentos para a realização desse encontro conformam o material analisado, bem como interações a que assisti e sobre as quais desenvolvi entrevistas em cafés, cartórios e corredores ${ }^{1}$.

Nos balcões dos cartórios judiciais comparecem advogados formados e em formação em busca de atendimentos relativos aos seus processos. Reputa-se que neste espaço os estudantes dos cursos de direito aprendem os conhecimentos práticos necessários para advogar, ao lidar com o cartório e entender seu funcionamento, conhecer o fórum e os desafios cotidianos da carreira. ${ }^{2}$

Os escreventes, por meio das rotinas cotidianas, aprendem com os funcionários mais antigos como desempenhar suas funções nos cartórios. O que será feito e como, o que se prioriza e qual a atribuição de cada funcionário são atividades determinadas por um conjunto de fatores internos. Pouco a pouco, escreventes judiciais aprendem como as coisas funcionam dentro do cartório em que trabalham.

Trata-se de uma rotina estratégica em ambos os lados do balcão. É preciso aprender as formas de interagir em um ambiente pautado pela hierarquia, formalismos, linguagem própria, trajes e espaços demarcados.

\footnotetext{
${ }^{1}$ Convém estabelecer aqui que a relação entre escreventes (e demais funcionários do judiciário) e os usuários leigos, partes processuais, não será analisada. Isto porque se, de um lado, podem ser considerados os "maiores interessados" no acesso à justiça - afinal, são suas as causas que tramitam no judiciário -, por outro, a especificidade de seus pedidos e o modo como são tratados os cidadãos que comparecem aos cartórios implicaria uma análise em separado, diferenciando-se das lógicas do acesso de advogados e estagiários.

2 Os precursores do método clínico de ensino no direito apontam que as faculdades de direito, tradicionalmente, oferecem uma formação teórica distanciada da prática jurídica, o que permite que os estágios profissionais tenham papel preoponderante na formação dos bacharéis, sendo necessário que os cursos incluam em suas grades conhecimentos práticos, por meio de atividades simuladas ou de assessoria, e aproximando ensino teórico da prática e repensando a formação pautada em decorar códigos e doutrinas que pouco são utilizadas na prática da profissão (FRANK, 1933; LAPA, 2014).
} 
O mundo da legalidade e das normas escritas revela-se nos balcões como passível de articulações, negociações e performances para alcançar objetivos. A interação neste espaço é tratada por quem está em lados opostos do balcão sob um mesmo mote, ainda que se lide com estratégias radicalmente diferentes: trata-se de fazer a máquina rodar, dar andamento aos processos.

Veena Das e Deborah Poole em seu texto El estado y sus márgenes: etnografías comparadas, afirmam que um dos enfoques relevantes do estudo das lógicas estatais seriam os espaços, formas e práticas "través de las cuales el estado está constantemente siendo experimentado y deconstruido mediante la ilegibilidad de sus propias prácticas, documentos y palabras" (2008, p.25).

Esses encontros no balcão, pode-se dizer, ocupam o lugar de práticas do dia-a-dia que permitem a experimentação e desconstrução das margens do judiciário. Se parece ser fixa a fronteira estabelecida pela fina placa de madeira, vidro ou plástico, entre aqueles que movimentam a máquina e aqueles que impulsionam seu movimento por meio de petições, despachos e ações, é por meio das estratégias de ambos os grupos que o balcão pode ser empurrado, contornado e até mesmo atravessado.

Dinâmicas locais de funcionamento do acesso à justiça são, muitas vezes, obscuras no interior de suas próprias estruturas. O cotidiano dos fóruns e o universo simbólico que revelam os cartórios judiciais, como veremos, são considerados, até o momento, um universo ainda desconhecido e pouco explorado pelas pesquisas (ALVES DA SILVA, 2007).

Para a realização da análise dialoguei sobretudo com a obra de Erving Goffman, estudioso das interações cotidianas, as quais analisou sob diversas perspectivas e ênfases em um projeto intelectual rico que pretendia "observar as formas de organização e as estruturas da vida social" (NIZET; RIGAUX, 2016, p.107). Sua obra, após mais de três décadas de seu falecimento, continua proeminente em produções de diversas áreas das ciências humanas e sociais aplicadas (MARTINS, 2011).

Diante da vasta produção de Erving Goffman destaco aqui a faceta que interessa a este trabalho: é ao observar condutas e rotinas tidas como "menores", menos relevantes no cotidiano, que o autor produz análises sobre nossa sociedade, trazendo à tona relações sociais construídas pela presença mútua de indivíduos, regras e ritos de interação social (2011), performances, expectativas e comunicações orais (2009), bem como a especificidade das interações ocorridas especialmente em lugares públicos (2010). E é a partir desta bibliografia que aprofundo as reflexões acerca do cotidiano jurídico visto a partir dos balcões, indagando 
sobre as interações que ali ocorrem e buscando compreender seu funcionamento à luz de um "saber local” (GEERTZ, 2009, p.249).

Ainda, sobre o tema dos balcões, o Conselho Nacional de Justiça (CNJ) editou a resolução 130 de 28 de abril de 2011, que busca padronizar o horário de atendimento nos fóruns do país. Tal resolução foi questionada pelo órgão de classe dos magistrados, a Associação dos Magistrados Brasileiros (AMB) por meio de uma Ação Direita de Inconstitucionalidade (ADIN), alegando que não caberia ao órgão intervir em decisões administrativas de cada Tribunal. O que me chamou a atenção naquele momento, e passou a compor o panorama deste trabalho, foi observar que o Conselho Federal da Ordem dos Advogados do Brasil (CFOAB), ao ingressar na causa na condição de amicus curiae, afirmou que a decisão do órgão não era de caráter meramente administrativo, mas buscava a garantia de um direito: o acesso à justiça. $\mathrm{O}$ acesso à justiça como direito fundamental presente nos balcões é, assim, dado do próprio campo de pesquisa, no qual as instituições disputam entendimentos acerca desse espaço.

Luís Roberto Cardoso de Oliveira defende que a antropologia poderia explorar melhor seu diálogo com o direito a partir de uma abordagem que considere as dimensões dos conflitos (direitos, interesses e reconhecimento) e as dimensões contextuais nas quais estão inseridos (seu universo simbólico, sua dimensão situacional e contextual) revelando, assim, "aspectos significativos dos conflitos e dos direitos que tendem a ser invisibilizados no judiciário" (2010, p.467).

Este trabalho delineia as formas dos conflitos no acesso ao judiciário, antes invisibilisados. Trata-se de um modo de destacar a importância de refletir sobre este cotidiano vivido por iniciados e sobre o que este cotidiano pode nos contar sobre o mundo do direito e suas conflituosidades, o modo como os processos e pessoas são geridos e qual o impacto disso no debate acerca do acesso à justiça.

Para delinear meu objeto de pesquisa e hipóteses provisórias, utilizei-me de minhas experiências como estagiária em diversas instituições judiciais na cidade de Campinas, interior de São Paulo.

Filas longas, reclamações, insatisfação generalizada com o próprio trabalho e com o atendimento recebido chamaram minha atenção no lado "de fora" dos cartórios. Pedidos de vista de processos constantemente negados, tensões e negociações de diversos tipos, despertaram meu "instinto etnográfico", nos dizeres de Peirano (2014), para a análise dessas interações. Por que o atendimento aos advogados e estagiários se dava em meio a tantos conflitos com os funcionários dos cartórios? 
"Do lado de dentro" dos cartórios, como estagiária, me vi fortemente afetada pelas relações institucionais que, para além do trabalho desempenhado, mobilizavam o dia a dia de meus colegas de trabalho. Fui apresentada a diferentes formas de apreender a rotina de trabalho das burocracias, modos de vestir, de se comportar e de desempenhar a lida diária.

Lógicas próprias e pressões internas tornavam esses espaços de trabalho extremamente complexos, com rígidas funções para cada um dos servidores. Acompanhei tensões diversas, adoecimentos e até fui testemunha em um processo de assédio moral no ambiente de trabalho ${ }^{3}$.

Interessada nos dramas humanos e institucionais destes espaços de trabalho do judiciário, passei a perscrutar o que interações entre escreventes dos cartórios, advogados e seus estagiários poderiam significar a respeito da experiência do acesso à justiça e do cotidiano de trabalho dos fóruns. Uma investigação sobre espaços dos quais pouco se fala nos manuais de direito, e a despeito do lugar de menor importância atribuídos a esses atores nos debates sobre a justiça e sua administração ${ }^{4}$.

Para o desenvolvimento da pesquisa, foi necessário localizar este trabalho no debate sobre as possibilidades de desenvolvimento de uma pesquisa interdisciplinar a partir da faculdade de direito e a construção de uma rede de interlocutores, o que descrevo a seguir.

\section{A Antropologia e o diálogo com as pesquisas jurídicas}

Diversos autores e autoras têm se manifestado a favor de uma produção nacional e mais intensa - na área de Antropologia do Direito, com distintas ênfases (SCHRITZMEYER, 2010; OLIVEIRA, 2010; SOUZA LIMA (ORG.), 2012; SCHUCH, 2010; dentre outros). Passando ao largo do debate sobre uma Antropologia do Direito, Antropologia $e$ Direito e Antropologia Jurídica, e do que seria o elemento central definidor de uma pesquisa empírica em direito, ressalto aqui a importância de colocar este trabalho,

\footnotetext{
${ }^{3}$ Ainda durante o estágio em direito, FR, analista judiciário há quase 20 anos, expondo sua sensação de impotência ante a estrutura na qual trabalhava, me aconselhou: "se você quiser voltar a esta instituição para trabalhar depois de se formar, não faça como a gente. Estude em um concurso para ser martelo, e não para ser prego. A gente só apanha."

4 Na graduação, realizei meu trabalho de conclusão de curso sobre o tema, denominado "Cartórios Cíveis em Campinas: Uma Perspectiva Antropológica”, sob a orientação do Professor e magistrado José Henrique Rodrigues Torres.
} 
de maneira ampla, dentre aqueles que se propõem a, a partir do olhar antropológico investigar o fazer jurídico.

Roberto Kant de Lima e Bárbara Baptista justificam o desenvolvimento de pesquisas nesta área, dentre outros motivos, pela necessidade e importância de nos debruçarmos sobre as rotinas e procedimentos que são desconhecidos pela maior parte das pessoas, mesmo aquelas que atuam na área, e que destoam do conteúdo ensinado nos ambientes universitários jurídicos (LIMA; BAPTISTA, 2014).

Os autores defendem a etnografia como metodologia aplicável para desvelar a realidade que se coloca para além dos discursos manualizados, reproduzidos em salas de aula no âmbito dos cursos de direito, conhecidos por seu mundo do "dever ser", de modo que "o trabalho de campo e especialmente a etnografia permitem perceber valores e ideologias diferentes daqueles que informam explicitamente os discursos oficiais do campo". No caso do Direito, afirmam os autores, "é certo que o discurso teórico produzido no campo nem sempre encontra correspondência nas práticas judiciárias, e vice-versa". De modo que isso ocorre especialmente uma vez que "existe, para além disso, uma completa invisibilidade dos valores e da ideologia que norteiam os mesmos rituais" (LIMA; BAPTISTA, 2008, p. 05).

Assim, a antropologia, seus métodos e modelos teóricos, têm sido vistos como possibilidades de investigação e interpretação dos conteúdos em disputa dentro do funcionamento do Estado, sob novos pontos de vista, jamais "únicos" ou "melhores", frisese.

A crescente produção sobre as instituições judiciais parece ter apenas tangenciado o tema dos cartórios e escreventes judiciais e as rotinas de advogados e estagiários a eles relacionadas. A importância de nos dedicarmos ao tema reside, assim, não apenas no potencial reflexivo que oferece, mas sobretudo na invisibilidade que envolve o tema em trabalhos acadêmicos.

Importante destacar que o interesse pelos balcões pode ser considerado, à primeira vista, como inexpressivo ou irrelevante para o estudo do direito, da antropologia ou para o contexto do poder judiciário e os desafios a ele colocados. Segundo Leirner (2014, p. 87) ainda persistem debates sobre objetos "certos" ou "errados" para estudos antropológicos, mas isso deve ser deixado para trás ou, ao menos, atualizado.

Veena Das e Deborah Poole afirmam que 
por razones que tienen que ver con sus orígenes históricos del estudio de los pueblos primitivos, la antropología tradicionalmente no ha reconocido al estado como objeto apropiado para la inspección etnográfica (DAS; POOLE, 2008, p.20).

Como apontam Beviláqua e Leirner, o que é central ou periférico dentro dos estudos do Estado e da burocracia está em constante debate em um campo de estudo que, a partir da antropologia, é recente e diferente em relação à política e à sociologia. Para esses autores "divisores como distante e perto, marginal e central são pouco operativos em si, e especialmente para a antropologia de setores estatais" (2000, p.102).

Entendo que este trabalho está na fronteira interdisciplinar entre antropologia e direito. Se por um lado trata-se de uma análise antropológica de um conjunto de significados em disputa nos balcões judiciais, o objeto é também jurídico. Andamentos, decisões, pedidos de vista em processos e todas as atividades que são feitas nesses atendimentos são elementos que estão no centro dos debates sobre a administração da justiça, sob o nome de produtividade, celeridade e eficiência do judiciário.

O uso do referencial teórico da antropologia e de seus recursos metodológicos, dentre eles a etnografia, em pesquisas de outras áreas de conhecimento, como o proposto na presente pesquisa, tem sido problematizado. Assim, é importante situar que este trabalho, ciente do debate acerca do uso meramente "instrumental" do ferramental teórico e metodológico da antropologia em contraposição a uma pesquisa etnográfica, com apropriação do fazer antropológico, questiona, justamente, se seria possível um uso "meramente instrumental" da etnografia.

Para Mariza Peirano a antropologia está constantemente se reinventando e "é resultado de uma permanente recombinação intelectual”. A autora afirma, ainda, que "métodos podem e serão sempre novos, mas sua natureza, derivada de quem e do que se deseja examinar é antiga" (2014, p. 381). Para a autora o resultado central do trabalho de campo é o despertar de realidades e agências desconhecidas no senso comum, colocar-nos em perspectiva, vulnerar nossa cosmologia.

Ainda, nos dizeres de Cláudia Fonseca:

(...) não existe método sem calcanhar-de-aquiles. É obviamente importante fazer a exegese sistemática de qualquer método eleito pelo pesquisador, refletindo sobre suas fragilidades. No entanto, em certos casos, este processo de "eterna autovigilância epistemológica" leva a uma espécie de paralisia. (...) Reconhecer os limites inevitáveis do método (seja ele etnográfico ou não) tem efeito contrário: libera o pesquisador para explorar ao máximo as vantagens de sua proposta. (FONSECA, 2000, p.08) 
Dessa forma, assumo este trabalho como etnográfico e jurídico, permitindo-me transitar nas fronteiras entre antropologia, direito e pesquisa empírica, assumindo desde já que esta postura pode e deve ser problematizada. Essa problematização constante e a tentativa de abandono dos antigos "divisores" é, acredito, um dos logros da existência de uma área de concentração interdisciplinar em Direitos Humanos na Faculdade de Direito da Universidade de São Paulo, que permite essas experimentações com fronteiras antes consideradas estáticas.

\section{Materiais analisados: conhecendo e entrevistando meus interlocutores}

Para a construção de meu campo e de minha rede de interlocutores, busquei percorrer os caminhos que se abriram para mim até os balcões de diversos fóruns de São Paulo, a partir das experiências de contatos tecidos ao longo dos anos de pesquisa a partir da Faculdade de Direito da Universidade de São Paulo (FDUSP), sendo as descrições e relatos que compõem este trabalho algumas dentre as inúmeras possibilidades interpretativas e descritivas dessa realidade.

Em um primeiro momento de minha pesquisa, eu acreditava que precisaria estar continuamente apenas em um cartório, contudo as diferentes estruturas físicas dos cartórios são descritas de modo a diferenciá-los constantemente. "Cada cartório é um cartório"; "Em Itaquera não há a presença de advogados, pois a maior parte dos processos são da Defensoria Pública"; "Santo Amaro é o Fórum do atraso"; "Nossa Senhora do Ó é o primeiro Fórum digital do Tribunal de Justiça, mas lá é preciso ir despachar com o juiz para a juntada dos processos, de tanta dificuldade no processo digital"; "No Fórum trabalhista as coisas são tão pesadas, aquele prédio todo espelhado, que não me espanta tantos suicídios por lá”.

Nem verdade nem mentira, essas descrições nativas revelam conhecimentos locais, compartilhados entre advogados, estagiários e escreventes sobre suas realidades de trabalho.

Cada balcão parece representar, nas falas de meus interlocutores, uma parte do todo do sistema judiciário, em que elementos comuns a todos os cartórios se confundem com diferenças quantitativas, qualitativas e características pessoais que influem no serviço realizado. Desse modo, seria necessário, diferente da ideia inicial de permanecer em apenas 
um cartório e seu respectivo balcão, transitar nas narrativas de meus interlocutores e nos balcões aos quais me levavam.

Os desafios enfrentados pela antropologia contemporânea implicam, na visão de muitos autores, novas recomposições teóricas e métodos para pensar a realidade social, atualizando o modelo de fazer antropológico que pressupunha o afastamento de sua própria sociedade para uma realidade distante e isolada, transformação que permeia a trajetória da disciplina. A antropologia "em casa" (FONSECA, 2008), a "autoantropologia" (STRATHERN, 2014) e a etnografia "multi situada" (MARCUS, 1998) são algumas das discussões teóricas pertinentes neste cenário.

Marcus aponta que a pesquisa multi-situada é uma das saídas para os novos problemas de pesquisa e realidades que a antropologia tem se proposto a pesquisar. Esta metologia é desenhada ao redor de cadeias, caminhos, fios, conjunções e justaposições de locais em que o etnógrafo estabelece alguma forma de presença, com o objetivo explícito de promover a associação ou conexão com vistas a definir os contornos do argumento etnográfico (1998, p.90). Como maneiras de desenhar este local multi-situado da pesquisa, o autor sugere que o pesquisador siga pessoas, objetos, metáforas, enredos, biografias. No caso da antropologia do direito, aponta que perseguir o conflito mostrou-se uma das maneiras mais estabelecidas de realizar a etnografia multi situada (idem, p.95).

Considerando que nenhum balcão ou cartório pode ser tido como exemplar, representativo do todo, e que tampouco é o objetivo deste trabalho a generalização, passei a transitar pelas narrativas e espaços. Buscava, a partir da perspectiva de uma etnografia multisituada, observar a diversidade de espaços com que tive contato e reconstituir o que há em comum nas experiências e conflitos acerca dos encontros no balcão.

Em linhas gerais, minha pesquisa de mestrado é informada pelos seguintes materiais:

a) Experiência prévia de coleta de informações e questionários na cidade judiciária de Campinas, em 2012;

b) Inserção em campo por meio de visitas, observações, conversas informais e entrevistas no Fórum João Mendes Jr. entre os anos de 2014 e 2016 com advogados, estagiários e funcionários (escreventes e diretores) do fórum, em varas cíveis e de família;

c) Entrevistas com escreventes que são alunos e alunas da FDUSP e que me indicaram conhecidos - magistrados e outros escreventes - para entrevistas, o que possibilitou minha entrada em campo; 
d) Entrevistas e idas a campo com estagiários do Departamento Jurídico XI de Agosto, da FDUSP;

e) Materiais advindos da pesquisa realizada pelo Instituto de Pesquisa Econômica Aplicada (IPEA) no ano de 2015 em juizados especiais cíveis e criminais no interior do estado e na cidade de São Paulo, na qual atuei como assistente de pesquisa entrevistando escreventes, diretores de cartório e magistrados em seis diferentes cartórios;

f) Entrevista com a equipe que organiza o ranking de cartórios denominado "De Olho no Fórum" da AASP- Associação de Advogados de São Paulo;

g) Análise de matérias e publicações nos canais oficiais do Tribunal de Justiça de São Paulo sobre as novas estratégias modernizantes e formação de servidores.

Ao realizar meu trabalho de conclusão de curso em 2012 constatei que precisaria pensar minha abordagem de maneira diferente para os profissionais do direito envolvidos nos atendimentos aos balcões: advogados e seus estagiários e escreventes judiciais. ${ }^{5}$

Abordados espontaneamente nos espaços dos fóruns, os advogados e estagiários se disponibilizavam para a pesquisa, indicavam as varas mais "problemáticas" a seu ver, compartilhavam suas estratégias e interpretações sobre o espaço de atendimento.

A presença em maior número de advogados e estagiários na área cível da cidade de Campinas, em detrimento da presença das partes, pessoas leigas buscando informações, pontuou um elemento chave na construção de minha pesquisa no mestrado ${ }^{6}$.

Escolhi o Fórum João Mendes Júnior (João Mendes), localizado a poucas quadras da FDUSP, onde estão instaladas diversas varas judiciais (nenhuma criminal, frise-se) e circulam alunos e professores da faculdade, permitindo ume entrada em campo produtiva.

Entre minhas colegas da Clínica de Direitos Humanos ${ }^{7}$, projeto de extensão da faculdade que coordeno pedagogicamente desde o ano de 2014, algumas que compunham o

\footnotetext{
${ }^{5}$ Sobre a diferença ao acessar funcionários e usuários produzi o paper "O desafio da pesquisa empírica nos contextos da burocracia judiciária: aqui as coisas não funcionam assim", apresentado na Universidade de Campinas - UNICAMP - nas Jornadas de Antropologia John Monteiro, em 2014.

${ }^{6}$ Friso aqui que observei em minha pesquisa que o acesso apenas por profissionais do direito aos fóruns não é um dado de campo simples. Em fóruns criminais, com a necessidade de assinar a "carteirinha", ou seja, apresentar-se ao cartório constantemente para demonstrar o cumprimento da pena, ou para as audiências, há a presença de muitas pessoas que figuram nos processos como partes processuais. $\mathrm{O}$ mesmo valeria para os juizados especiais em que as pessoas podem atuar sem o intermédio de advogados. Por sua vez, em fóruns cíveis, nos quais a maior parte dos processos ocorrem sem a presença das partes, mas sim por meio de seus procuradores, era de se esperar que apenas estes fossem aos cartórios, tal como observei em Campinas. Contudo, foi-me apontado que em fóruns cíveis em que há grande atraso, e que o atendimento é feito majoritariamente pela defensoria - e que, assim, não dispõe de um atendimento individualizado como seria ofertado por um escritório de advocacia - as partes vão constantemente ao fórum para ter notícia de seus processos, entender os andamentos, perguntar o que está acontecendo. Assim, não se pode ser generalista quanto ao público de cada um dos fóruns.

${ }^{7}$ Paralelamente às atividades do mestrado, atuo na coordenação pedagógica deste Projeto de Extensão, que trata dos direitos da população em situação de rua na cidade de São Paulo.
} 
projeto haviam sido estagiárias de magistrados e poderiam me apresentar a eles e aos funcionários de seus cartórios. Outras pretendiam prestar o concurso para o cargo de escrevente, ou conheciam alguém que desempenhava esta função no Fórum João Mendes Júnior.

Assim, o campo foi se abrindo neste espaço, que passei a visitar com regularidade durante o período de campo, no ano de 2015, e pontualmente em 2016, abordando advogados e construindo oportunidades para entrevistas com funcionários e magistrados.

Ainda, por meio das estudantes, conheci o Departamento Jurídico XI de Agosto, entidade de assistência jurídica autogestionada por alunos e alunas da FDUSP. Ao iniciarem os trabalhos neste espaço de atendimento jurídico à população em condições de vulnerabilidade social em São Paulo, os estudantes ingressantes, "calouros”, devem realizar, como primeiras atividades de formação, antes de se tornarem estagiários jurídicos dos casos, a triagem dos atendimentos e a "vareiragem".

"Vareirar" ${ }^{8}$ significa coletar fichas de pedidos dos advogados e estagiários de cada caso e ir ao fórum cumprir as tarefas, ou como eles chamavam muitas vezes, "missões". Acompanhei algumas idas "a campo", ou seja, aos fóruns, para compor o material desta pesquisa.

Por atuar no meio jurídico como acadêmica e pesquisadora, muito material chegou a mim de maneira muito difusa. Amigas, amigos e colegas me mandavam e-mails e mensagens com seus "causos" jurídicos. Refletindo sobre essas conversas, muitas formalizadas como entrevistas enquanto outras foram apenas conversas informais, encontrei respaldo nos termos de Mariza Peirano (2014) que aduz que a experiência etnográfica não tem momento para começar ou terminar.

Os contínuos contatos interpessoais com pessoas que atuam no direito me serviram para apurar o olhar, afastar-me e aproximar-me de coisas antes naturalizadas e que passei a estranhar e a relatar em meu caderno de campo. Tal feito, aliás, produziu em mim uma constante renovação no desejo de perquirir esse espaço.

Ainda, ao final de 2014, fui selecionada pelos coordenadores de pesquisa Alexandre Cunha e Bernardo Medeiros para compor um grupo de pesquisadores sobre a

\footnotetext{
${ }^{8}$ Analogamente, em escritórios particulares os estagiários “fazem fórum", justamente requerendo e olhando os processos indicados pelos advogados de seus escritórios, outros termos, mais comuns, que designam a mesma atividade.
} 
desburocratização dos juizados especiais cíveis e criminais no estado de São Paulo, em relatório já disponível para consulta?

A importância desse espaço para advogados - não apenas individualmente, mas para a classe profissional como um todo - também pode ser observada por meio da existência de um ranking de avaliação dos fóruns, realizado pela Associação dos Advogados de São Paulo (AASP) cuja equipe entrevistei, com a autorização do presidente da associação.

Diante do amplo material coletado, selecionei entrevistas, conversas e observações em espaços sobre os quais trabalhei de maneira mais detida na produção desta dissertação, todas realizadas entre novembro de 2014 e dezembro de 2015, os quais organizo a seguir:

Tabela 1 - Entrevistas e conversas registradas com interlocutores da pesquisa

\begin{tabular}{|c|c|c|}
\hline Local & $\begin{array}{l}\text { Pessoas Entrevistadas } \\
\text { formalmente }\end{array}$ & Conversas informais registradas \\
\hline Fórum João Mendes Júnior & $\begin{array}{l}\text { Três magistrados, uma } \\
\text { diretora, seis } \\
\text { escreventes }\end{array}$ & $\begin{array}{l}\text { Dez advogadas, seis advogados, quatro } \\
\text { estagiários de direito; Três diretores, oito } \\
\text { escreventes, três estagiários dos cartórios. }\end{array}$ \\
\hline Fórum da Barra Funda & $\begin{array}{l}\text { Três escreventes, uma } \\
\text { diretora de cartório. }\end{array}$ & Duas advogadas. \\
\hline $\begin{array}{l}\text { Juizados Especiais Cíveis da } \\
\text { cidade de São Paulo }\end{array}$ & $\begin{array}{l}\text { Um diretor de cartório, } \\
\text { três magistrados. }\end{array}$ & Seis advogados. \\
\hline $\begin{array}{l}\text { Juizados Especiais Cíveis e } \\
\text { Criminais do interior do } \\
\text { estado de São Paulo }\end{array}$ & $\begin{array}{l}\text { Três diretores, seis } \\
\text { escreventes. }\end{array}$ & Quatro advogados, dez escreventes. \\
\hline 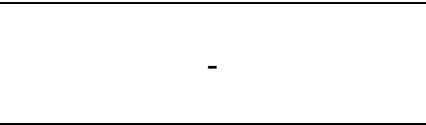 & $\begin{array}{l}\text { Três advogados e seis } \\
\text { advogadas; Equipe da } \\
\text { AASP. }\end{array}$ & Quatro advogadas. \\
\hline
\end{tabular}

Por fim, em acesso constante ao site do Tribunal de Justiça do Estado de São Paulo, e observandoos murais dos fóruns, busquei conhecer as notícias e cursos realizados nesses espaços voltados aos servidores e que noticiavam as constantes mudanças nos procedimentos do Tribunal.

Nos termos de Cláudia Fonseca “os dados não falam por si mesmos, são moldados pelo pesquisador a temas de debate pertinentes ao campo acadêmico" (2000, p.7). Sabendo que faço uma escolha dentre as muitas possíveis ao descrever e analisar esses espaços a partir de meu olhar em campo, opto por explorar o cotidiano de meus interlocutores, escreventes, advogados e estagiários a partir de fragmentos de suas narrativas, que organizam a segunda

\footnotetext{
${ }^{9}$ IPEA. Desburocratização dos cartórios judiciais: Análise dos juizados especiais do Tribunal de Justiça de

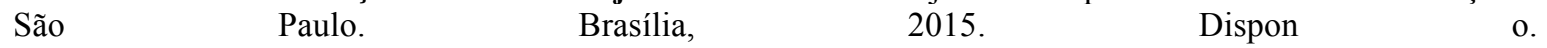
juizahttp://www.ipea.gov.br/portal/images/stories/PDFs/relatoriopesquisa/151216_relatorio _desburocratizacao.pdf. Ú tp://www.ipea.gov.br/portal/images/st
} 
parte deste trabalho: o aprendizado que ocorre por meio da realização dos atendimentos, como as roupas e regras de deferência compõem essas interações e rituais destes espaços e como a "pressão"emocional e de ritmo de trabalho é elemento inerente a esse cotidiano.

Ainda, na terceira parte deste trabalho, pude analisar o material coletado de modo a constatar a forte hierarquização deste espaço, que é atualizada cotidianamente nos balcões e atendimentos realizados. A administração da justiça, como objeto de estudo, necessita apropriar-se, na perspetiva deste trabalho, dos dilemas interpessoais que se colocam nessas relações de trabalho permeadas por sujeições, relacionamentos pessoais e autoritarismos.

Passo, antes da apresentação dos dados coletados em campo e da análise, a realizar uma discussão interessada acerca do acesso à justiça e seu diálogo possível com os balcões de atendimento. 


\section{CONSIDERAÇÕES FINAIS:}

A presente dissertação de mestrado marca o fim de um período de pesquisa de três anos. A forma com que construí o texto reflete a trajetória da pesquisa e alguns dos debates enfrentados ao longo deste percurso. Uma pesquisa interdisciplinar que tem por objeto os balcões judiciais, espaço considerado em declínio ante as estratégias modernizantes adotadas pelo tribunal, e cujo fim estaria selado com o adensamento da informatização nos tribunais, demandou uma pesquisa que possibilitasse o trânsito entre antropologia e direito, entre os temas jurídicos inerentes a estes espaços e o os materiais que pude coletar em minhas observações.

O texto divide-se, assim, em uma primeira parte que busca delinear interpretações possíveis do direito fundamental do acesso à justiça e um breve panorama dos estudos feitos sobre os cartórios judiciais e seus balcões. A bibliografia sobre o tema dos cartórios e seus escreventes, especialmente a partir das faculdades de direito, mostrou-se escassa e dá pistas do que apresento na segunda e terceira parte deste trabalho. A invisibilidade construída ao redor destes espaços dialoga com o tratamento dirigido a aqueles que compõem o dia a dia dos cartórios e que neles interagem.

Os esforços para a resolução da "crise da administração da justiça", em debate desde os anos 80 no Brasil, têm se mostrado pouco transformadores da realidade do judiciário, que segue uma estrutura considerada "pesada" e "morosa" na resolução de conflitos, e cujo ativismo nos movimentos sociais, e mais atualmente de maneira incisiva nos processos políticos, têm despertado o interesse científico.

As recentes normativas sobre a gestão de pessoas no judiciário, com especial destaque para a Política Nacional de Gestão de Pessoas no Âmbito do Poder Judiciário (Resolução 240 de 2016) demonstram a visibilidade crescente do tema dos cartórios e seus funcionários e de um necessário olhar para o tema, apontado tanto nas pesquisas de estudo de caso quanto nos censos realizados pelo CNJ.

Sem apontar saídas definitivas, é possível notar algumas lacunas nas reformas realizadas a partir do material sistematizado nesta pesquisa.

Em primeiro lugar, as formas de resolução de conflitos pelo judiciário, os processos, têm sido objeto de reformas. No entanto, a forma de lidar com os processos conserva elementos ligados aos privilégios de um tipo de trabalho que, cultivando um modo 
de ser hierarquizado, não admite correções, questionamentos. Pedidos não apreciados, andamentos equivocados fazem parte do cotidiano dos balcões de atendimento, para além das demoras muitas vezes imprevisíveis para cada andamento processual. Escreventes e advogados, ao apontarem erros, ao "baterem de frente" com os magistrados, correm o risco de se "indisporem", e ninguém quer se indispor com a figura de mais alta hierarquia no espaço, cuja autoridade deve ser mantida, bem como, cada um em seu devido lugar. É preciso, da perspectiva do material que coletei, questionar os laços de subordinação inerentes à estrutura do judiciário que permanecem intocados, a despeito da modernização das formas de tramitação, e construir novas formas de interação entre estes indivíduos.

Os aspectos emocionais dessa burocracia, ainda, têm sido pouco estudados e quiçá subestimados nestes contextos. Nos termos de REZENDE e COELHO (2010, in CARNEIRO, 2013), os sentimentos são demonstrados na interação social, e a linguagem tem papel fundamental em sua transmissão. Para as autoras, as emoções, a um só tempo, moldam e nomeiam o social, vindo, por isso, atravessadas por relações de poder, hierarquias e concepções de moralidades que desenham fronteiras entre grupos.

O caráter micropolítico das relações, e em específico, das relações entre as peças que compõem a máquina do judiciário, é tema que pode mostrar-se central para o desenvolvimento de pesquisas qualitativas na burocracia e de uma transformação possível em suas estruturas e rotinas.

As demandas são simples e menos tecnológicas do que a informatização: é preciso espaços de troca entre funcionários, é preciso que a atribuição de funcionários em cada cartório não seja feita de maneira política, é preciso transformar a relação entre funcionários na burocracia judiciária.

Aos advogados, aprender estratégias para lidar com a máquina é um processo que ocorre junto a um desencantamento com a justiça - que não está nos balcões, despachos ou sentenças - e com a construção de uma imagem social específica dos indivíduos que estão ali nos balcões. As "peças da máquina" devem ser tratadas com a educação necessária para que se obtenha o que for preciso para o processo andar, é preciso, jogar com sua visibilidade e invisibilidade.

Este trabalho foi realizado a partir da construção de uma rede de interlocutores, mas, também da construção de um imenso sentimento de afetação por narrativas e histórias de vida que, invisibilizadas nas estruturas e nas pesquisas acadêmicas, encontraram muitas vezes em mim uma forma de desabafo.

Ao narrar e experimentar novamente sentimentos em relação ao ambiente de 
trabalho, meus interlocutores indicaram sua insatisfação especialmente diante da contradição do tratamento humilhante vivenciado em uma estrutura responsável pela realização da justiça em nossa sociedade.

Qual a diferença entre os que estão no topo da hierarquia e os funcionários que permite um tratamento tão distanciado? O debate político e social que vivemos, que tem denunciado privilégios e supersalários existentes legalmente em nosso sistema, reverbera nos corredores dos fóruns. É preciso um rearranjo que crie novos parâmetros de igualdade no mundo jurídico.

Atribuo à contradição entre o fazer justiça e ser peças de uma máquina, jogadores em jogos de interação vazios de conteúdo da justiça, muito da angústia dos profissionais dentro e fora dos balcões.

Alguns optam por distanciar-se dos sentimentos, outros por obedecer sem questionar, e há aqueles que canalizam sua indignação em outras tarefas ou aspectos de suas vidas para não adoecerem. Aqui a gente enrijece ou enlouquece.

Por parte dos advogados, o descrédito com a estrutura de poder permite um tratamento crescentemente estratégico. A falta de confiança nas decisões faz com que, por vezes, os advogados busquem compor acordos, acelerar o processo para a segunda instância, fazer reuniões com magistrados "apresentando" processos e pedindo que apreciem a causa, sem fazer julgamentos em lote. As estratégias multiplicam-se, nenhuma delas no sentido de melhorar a prestação jurisdicional, de buscar estabelecer padrões de qualidade de decisões e despachos ou, ao menos diálogo. Não há espaço para isso e, novamente, niguém quer se “indispor" com a estrutura de funcionamento do tribunal.

O desenho institucional dos cartórios, varas, tribunais superiores está em disputa em âmbitos que não o “chão de fábrica”. Premiações, sugestões, fóruns de debates em regra não dão espaço aos servidores.

Recentemente ouvi de um desembargador, já finalizado o período de pesquisa em campo, que nos cursos online do tribunal evitava-se que magistrados e escreventes fizessem o curso juntos. Para evitar que os juízes se sentissem expostos para tirar dúvidas diante de seus funcionários - afinal, juízes não podem ter dúvidas, pensei - e também por que os servidores confundiam os canais de comunicação, e logo que lhes era concedida a palavra começavam a falar que seu juiz faz isso, seu juiz faz aquilo, e se isso estaria certo ou errado, e o objetivo do curso não era ficar ouvindo reclamação de escreventes.

Mesmo fora do escopo deste trabalho, acessei algumas informações sobre os juízes. Também estão inseridos em uma forte lógica de hierarquia que aprendem no desenolvimento 
da função, seus questionamentos são silenciados e, entre os recém ingressos na carreira, é considerada uma afronta de moleques, segundo um juiz entrevistado, podendo sofrer vígilia da corregedoria sempre que seu comportamento sair dos parâmetros esperados, também no que tange à gestão dos cartórios.

$\mathrm{O}$ desrespeito às regras da hierarquia compartilhadas nestes espaços gera punições também aos juízes. A demora na ascensão aos cargos em primeira entrância ou de instâncias superiores é um dos exemplos de "punição" mais comuns. Muitos dos estudos sobre a saúde dos magistrados apontam para um adoecimento resultante do ambiente de trabalho e pressões internas, para além daquelas decorrentes do exercício da função juridicional (COSTI, 2013). A resolução de número 207 de 2015 do CNJ, que institui Política de Atenção Integral à Saúde de Magistrados e Servidores do Poder Judiciário, denota também a crescente importância do tema da saúde de magistrados e servidores no ambiente de trabalho.

A dificuldade de acessar os discursos locais sobre o funcionamento da máquina, a lógica do segredo que permeia as funções desempenhadas, parece ser um elemento importante para reflexão, ao fim deste trabalho. O que aconteceria se os escreventes pudessem falar, se pudessem ser ouvidos? Quais as narrativas a que teríamos acesso se magistrados, magistradas e advogados, para além das linhas e fachadas aprendidas ao longo dos anos de carreira, pudessem analisar suas funções, cargos e modos de operar a máquina? Seria possível uma diminuição nos níveis de hierarquização desta estrutura? Essa hierarquização é compatível com a produção da justiça?

$\mathrm{O}$ balcão, e a hierarquia ritual que pode ser vista, não está circunscrita àquele espaço. Ele apenas atualiza um funcionamento que orienta toda a estrutura e que afeta a todos os seus integrantes. Considerá-la circunscrita, como afirma Da Matta, permite que consideremos as tensões e disputas ali colocadas como expressão de revoltas locais, e não sintoma de uma crise, de um conflito institucional.

Os embates, as disputas mencionadas e descritas neste trabalho, ocorrem no balcão sobre como ou quão rápido os processos devem andar. As tensões inerentes a essas interações, disputas de argumentos e fachadas ao balcão, tornam manifestos os conteúdos encobertos: a máquina está emperrada, vir ao balcão é uma tentativa de fazer suas engrenagens moverem-se; não se pode contestar de qualquer maneira, é preciso aprender a "jogar o jogo" dos tribunais, que não tem a ver apenas com o direito e com a normas processuais.

Descrever o cotidiano de fóruns e seus balcões, lógicas de funcionamento cotidianas e em geral restritas a aqueles que os frequentam não é "descobrir" relações 
desconhecidas. Trata-se do exercício de descrever as interações ali colocadas e se perguntar sobre os motivos que nos levam a reproduzir essas lógicas de funcionamento que, conforme vimos, impactam os envolvidos.

O diálogo dentro da instituição, a diminuição das distâncias interpessoais e o aprofundamento das noções de igualdade e cidadania no mundo jurídico poderiam, sob o prisma do material coletado neste trabalho, promover um abandono de fachadas que encaram as disputas e tensões destes espaços como questões locais e passar a tratá-las como uma crise digna de esforços para seu enfrentamento. Os "jeitinhos" locais aos processos, e o temor de indispor-se com a estrutura poderia dar lugar, idealmente, a um debate a modernização do funcionamento que não tem modernizado as relações entre pessoas no mundo do direito.

Acredito que é na busca da compreensão desta contradição entre a mecanização e a justiça, entre as fachadas e o acesso aos direitos, entre a operação da máquina e o fazer da justiça, que podemos encontrar pistas para ver novas questões e pensar outras reformas desta estrutura, cujas modernizações constantes têm levado a poucos avanços. 


\section{REFERÊNCIAS BIBLIOGRÁFICAS:}

ALMEIDA, Frederico Normanha Ribeiro de. A nobreza togada as elites jurídicas e a política da justiça no brasil Tese (Doutorado). Ciência Política. FFLCH-USP. 2010.

As elites da Justiça: instituições, profissões e poder na política da justiça brasileira. Rev. Sociol. Polit., v. 22, n. 52, p. 77-95, dez. 2014 DOI 10.1590/1678987314225206

ALVES DA SILVA, Paulo Eduardo (coord.) Análise de Gestão e Funcionamento dos Cartórios Judiciais. Brasília: Ministério da Justiça, 2007.

ALVES DA SILVA, Paulo Eduardo (superv.); SCHRITZMEYER, Ana Lúcia Pastore (coord.). Uma etnografia dos cartórios judiciais. Estudo de caso em cartórios judiciais do Estado de São Paulo. CADERNOS DIREITO GV , v.5 n.4,. São Paulo: Direito GV, 2008.

ALMEIDA, Guilherme de. Acesso à justiça, direitos humanos e novas esferas da justiça. Contemporânea - Revista de Sociologia da UFSCar. São Carlos, v. 2, n. 1, jan-jun 2012, pp. 83-102.

AQUINO, Jania Perla Diógenes de. Príncipes e Castelos de Areia: performance e liminariedade no universo dos grandes roubos. Tese (Doutorado) Antropologia Social. FFLCH. São Paulo, 2009. 
BAPTISTA, Bárbara Gomes Lupetti. "A minha verdade é minha justiça" - dilemas e paradoxos sobre o princípio da imparcialidade judicial. Revista cadernos de campo, São Paulo, n. 22, 2013.

BALANDIER, Georges. O poder em Cena. Brasília: Editora UNB, 1982.

BARRERA, Letícia. La corte suprema en escena. Uma etnografia de mundo judicial. Buenos Aires: Siglo veintiuno editores, 2012.

BERREMAN, Gerald D. Etnografia e controle de impressões em uma aldeia do Himalaia. In ZALUAR, Alba (org.). Desvendando máscaras sociais. Rio de Janeiro: Editora livraria Francisco Alves, 1975, pp. 123-174.

BEVILAQUA, Ciméa. Etnografia do Estado: algumas questões metodológicas e éticas. CAMPOS - Revista de Antropologia Social, Paraná, v.3, 2003, ISSN 1519-5538. Disponível em: < http://ojs.c3sl.ufpr.br/ojs2/index.php/campos/issue/view/169>. Acesso em 01 de outubro de 2014.

BEVILAQUA, Ciméa; LEIRNER, Piero de Camargo. Notas sobre a análise antropológica de setores do Estado brasileiro. Rev. Antropol. [online]. 2000, vol.43, n.2, pp. 105-140. ISSN 0034-7701. Disponível em: < http://dx.doi.org/10.1590/S003477012000000200006. . . Acesso em 01 de outubro de 2014.

BIANCAMANO, Mary da Rocha. O poder judiciário e o movimento da qualidade total: aspectos determinantes na implantação do PGQJ em um estudo exploratório. Dissertação (Mestrado) Escola de Administração - UFRGS. Porto Alegre, 1999. 
BLUMBERG, Abraham. The practice of law as a confidence game. Law \& Society Review. Vol. 1, No. 2 (Jun., 1967), pp. 15-40

BONELLI, Maria da Glória. A competição Profissional no mundo do direito. Revista Tempo Social, USP. São Paulo, v. 10, p. 185-214, maio de 1998.

. As interações dos profissionais do direito em uma Comarca do Estado de São Paulo. In SADEK, MT, org. O sistema de justiça [online]. Rio de Janeiro: Centro Edelstein de Pesquisas Sociais, 2010. O sistema de justiça. pp. 24-70. Disponível em: SciELO Books $<$ http://books.scielo.org $>$.

BONELLI, Maria da Gloria. CUNHA, Luciana G. OLIVEIRA, Fabiana L. de e SILVEIRA, Natália B. da. Profissionalização por gênero em escritórios paulistas de advocacia, Tempo Social, revista de sociologia da USP, v. 20, n. 1, pp. 265-290, junho de 2008.

BOTELHO, Renata Dias. PAIVA, Kely César Martins. Comprometimento organizacional: um estudo no Tribunal de Justiça do Estado de Minas Gerais. Revista de Administração Pública, Rio de Janeiro 45(5):1249-283, Set./out. 2011

BOURDIEU, Pierre. O poder simbólico. Rio de Janeiro: Editora Bertrand, 1989.

BRASIL. Lei complementar $\mathbf{n}^{\mathbf{0}} \mathbf{8 0}$, de 12 de janeiro de 1994

BRASIL. Ministério da Justiça. Diagnóstico do Poder Judiciário, 2004. 
BRAGA, Fernando. Homens invisíveis: relatos de uma humilhação social. São Paulo, Globo, 2004.

CAMPOS, Edmundo. Sociologia da Burocracia. Rio de Janeiro: Zahar Editores, 1976.

CAPPELlETTI, Mauro; GARTH, Bryant. Acesso à Justiça. Porto Alegre: Sergio Antonio. Fabris Editor, 1988.p.13.

CARDOSO DE OLIVEIRA, L. R. A dimensão simbólica dos direitos e a análise de conflitos. Revista de Antropologia USP, São Paulo, v. 53, 2011, p. 451-473.

CARMO, Marina Maia do. “Tribunal da cidadania?! Pra quem?!”: Qualidade de vida no trabalho em um órgão do Poder Judiciário brasileiro. Dissertação (mestrado) - Programa de Pós-Graduação em Psicologia Social, do Trabalho e das Organizações /UnB - Brasília, 2014.

CARVAlHO, José Murilo de. Cidadania: Tipos e Percursos, Revista Estudos Históricos, 1996-18

CAVEDON, Neusa. "Pra tá no DC tem que ser meio doido, se tu não és, vai ficar ": a saúde mental dos servidores do Departamento de Criminalística do Instituto-Geral de Perícias do Rio Grande do Sul FACECLA | Campo Largo - PR, Brasil. doi: 10.5329/RECADM.20121102006 RECADM | v. 11 | n. 2 | p. 255-271 | Jul-Dez/2012.

CLEMES, Johnny Gustavo. Método para funcionamento eficiente e eficaz de uma unidade judiciária: como a representação dos processos de trabalho por meio de 
fluxogramas pode revolucionar a prestação do serviço jurisdicional nos Juizados Especiais Cíveis. Dissertação (Mestrado Profissional em Poder Judiciário) Escola de Direito, FGV, Rio de Janeiro, 2010

CNJ: resolução 240 de 09 de setembro de 2016. Política nacional de gestão de pessoas no âmbito do poder judiciário.

: Censo nacional do judiciário: tjsp, 2013.

COSTI, Cíntia Gonçalves. A saúde do magistrado: Um breve levantamento bibliográfico.. REVISTA DA ESMESC, v. 20, n. 26, 2013

COELHO, Maria Cláudia; SENTO-SÉ, João Trajano; CASTRO, Anderson; ZILLI, Bruno. Interação, conflito e Emoção - o exercício da autoridade em revistas de malas em aeroportos. Trabalho apresentado na 29a Reunião Brasileira de Antropologia, realizada entre os dias 03 e 06 de agosto de 2014, Natal/RN.

CUNHA, Luciana G. BONELLI, Maria da Gloria. OLIVEIRA, Fabiana L. de e SILVEIRA, Natália B. da. Sociedades de advogados e tendências profissionais. Direito GV. V. 3 N. 2 | P. 111 - 138 | JUL-DEZ 2007

DAS, Veena. O ato de testemunhar: violência, gênero e subjetividade. Cadernos Pagu, Campinas, n. 37, pp. 9-41, Dec. 2011. Disponível em $<$ http://www.scielo.br/scielo.php?script=sci_arttext\&pid=S010483332011000200002\&lng=en\&nrm=iso>. Accesso em $05 \quad$ Jan. 2017. http://dx.doi.org/10.1590/S0104-83332011000200002. 
DAS ROS, Luciano. O custo da Justiça no Brasil: uma análise comparativa exploratória newsletter. Observatório de elites políticas e sociais do brasil. v. 2, n.9. 2015 . universidade federal do paraná (ufpr) núcleo de pesquisa em sociologia política brasileira (nusp)

DAMACENO, Ludmila Barros. O modelo burocrático e a gestão judiciária: caminhos para a celeridade processual. UESB. Cadernos de Ciências Sociais Aplicadas, Ano 8, $\mathrm{n}^{\mathrm{o}} 11$, jan/jun, 2011

DAMATTA, Roberto. Carnavais, malandros e heróis: para uma sociologia do dilema brasileiro. Rio de Janeiro, RJ: Rocco, 1997.

ESCOLA DE DIREITO DO RIO DE JANEIRO - Centro de Justiça e Sociedade. A REFORMA Silenciosa da Justiça. Fundação Getulio Vargas. Rio de Janeiro: 2006. 436 pp.

FIORENZE, Ricardo. Gestão da tramitação processual nas varas trabalhistas. Dissertação (Mestrado Profissional em Poder Judiciário), Escola de Direito, FGV, Rio de Janeiro, 2009.

FONTAINHA, Fernando de Castro. A informatização do processo do acesso à administração da justiça. Revista da SJRJ, Rio de Janeiro, n.26, p. 57-69, 2009. . Informatização da vida e dos tribunais do Brasil. Revista Direito FGV. V.3N.1| P.057-074 |JAN-JUN2007 
FONTAINHA, Fernando de Castro. GERALDO, Pedro Heitor Barros.VERONESE, Alexandre. ALVES, Camila Souza. Revista Jurídica da Presidência Brasília v. 16 n. 110 Out. 2014/Jan. 2015 p. 671-702.

FRANK, Jerome N., Why Not a Clinical Lawyer-School? (1933). Faculty Scholarship Series. Paper 4109. Disponível em: http://digitalcommons.law.yale.edu/fss papers/4109. Acesso em 05 de janeiro de 2017.

FULLIN, C. S. . Acesso à Justiça: a construção de um problema em mutação. In: SILVA, Felipe G.; RODRIGUEZ, José R.. (Org.). Manual de Sociologia Jurídica. 1ed.São Paulo: Saraiva, 2013, v. , p. 219-236.

GERALDO, Pedro Heitor Barros. A audiência judicial em ação: uma etnografia das interações entre juristas e jurisdicionados na França. Revista Direito GV, São paulo 9(2) | P. 635-658 | JUL-DEZ 2013

GEERTZ, Clifford. A interpretação das culturas. Rio de Janeiro: Guanabara Koogan, 1989.

.O saber local: novos ensaios em antropologia interpretativa - Petrópolis: Editora Vozes, 2009.

. Nova luz sobre a antropologia - Petrópolis: Editora Vozes, 1999.

GOFFMAN, Erving. Ritual de interação - Ensaios sobre o comportamento face a face. Petrópolis: Editora vozes, 2011. 
. A representação do eu na vida cotidiana. Petrópolis: Editora Vozes, 2002.

. Comportamento em lugares públicos. Petrópolis: Editora Vozes, 2009

. On Fieldwork. Journal of Contemporary Ethnography. Sage publications, 1989.

GOMES, Adalmir de Oliveira. GUIMARÃES, Tomás de Aquino. Desempenho no Judiciário. Conceituação, Estado da Arte e Agenda de pesquisa. Rev. Adm. Pública — Rio de Janeiro 47(2):379-401, mar./abr. 2013

GONÇALVES FILHO, José Moura. A invisibilidade Pública. In. BRAGA, Fernando. Homens invisíveis: relatos de uma humilhação social. São Paulo, Globo, 2004.

GRAHAM, Mark. Emotional Bureaucracies: Emotions, Civil Servants, and Immigrants in the Swedish Welfare State. Ethos. Vol. 30, No. 3 (Sep., 2002), pp. 199-226

GRIMSON, Alejandro. (org.). Antropología Ahora. Buenos Aires: Siglo veintiuno editores, 2011.

HESS, Heliana Coutinho. Políticas públicas aplicadas à gestão judicial. São Paulo: Escola Paulista da Magistratura. Disponível em: http://www.epm.tjsp.jus.br/Internas/Artigos/AcervoView.aspx?ID=18142 . Último acesso: 25 de outubro de 2016.

HERZFELD, Michael. The social Production of Indifference. Chicago: Chicago 
university Press, 1992.

JOSEPH, Isaac. Erving Goffman e a microssociologia. Rio de Janeiro: Editora FGV, 2000.

KAFKA, Franz. O processo. São Paulo: Companhia das Letras, 1997.

KANT DE LIMA, Roberto. Ensaios de Antropologia e de Direito. Rio de Janeiro: Editora Lumen Juris, 2011.

. Antropologia Jurídica. In: LIMA, Antonio Carlos de Souza (org). Antropologia e

Direito: Temas Antropológicos para estudos jurídicos. Brasília: Editora ContraCapa, 2012.

KANT DE LIMA, Roberto; LUPETTI BAPTISTA, Bárbara Gomes. O desafio de realizar pesquisa empírica no direito: uma contribuição antropológica. Disponível em: http://www.uff.br/ ineac/sites/default/files /o_desafio_de_realizar_pesquisa_empirica_no_direito.pdf

LAPA, Fernan Brandão e MESQUITA, Valena Jacob Chaves. Clínicas de Direitos Humanos. ARACÊ - Direitos Humanos em Revista, Ano 2, Número 2, Maio 2015.

LATOUR, Bruno. The making of law. -An Ethnography of the Conseil d'Etat. Cambridge: Polity Press, 2009.

LATOUR, Bruno; WOOLGAR, Steve. A vida de laboratório: a produção dos fatos científicos. Rio de Janeiro: Relume Dumará, 1997. 
LE BRETON, David. A sociologia do corpo/La sociologie du corps. 2a Ed. Tradução de Sônia M.S. Fuhrmann. Petrópolis: Vozes, 2007.

LIPSKY, Michael. Street-level bureaucrecy: dilemas of the individual in public services. New York: Russel Sage Foundation, 2010.

LOPES, José Reinaldo Lima. Reformar cartórios para reformar a Justiça. Folha de São Paulo, São Paulo, 20 dez. 2005, p. 3.

KANT DE LIMA, Roberto e BAPTISTA, Bárbara Gomes Lupetti, Como a Antropologia pode contribuir para a pesquisa jurídica? Um desafio metodológico, Anuário Antropológico [Online], I | 2014, posto online no dia 01 Outubro 2014, consultado no dia 24 Março 2016. URL : http://aa.revues.org/618 ; DOI : 10.4000/aa.618

MARCUS, George. Etnography Throuhgh Thick and Thin. USA: Priceton University Press, 1998.

MARQUES JR., G. Espaço do fórum, autoridade e representação: introdução a uma pesquisa na justiça. SADEK, MT., org. In Uma introdução ao estudo da justiça [online]. Rio de Janeiro: Centro Edelstein de Pesquisas Sociais, 2010. pp. 41-64. Disponível em SciELO Books $<$ http://books.scielo.org $>$.

MARTINS, Carlos Benedito. A contemporaneidade de Erving Goffman no contexto das ciências sociais. Rev. bras. Ci. Soc., São Paulo, v. 26, n. 77, p. 231-240, Oct. 2011 . Available from $\quad<$ http://www.scielo.br/scielo.php?script=sci_arttext\&pid=S010269092011000300019\&lng=en\&nrm=iso $>$. access on 18 Dec. 2016. http://dx.doi.org/10.1590/S0102-69092011000300019. 
MAUSS, Marcel. Sociologia e Antropologia. São Paulo: Cosac Naify, 2013.

MEDEIROS, Bernardo. CUNHA, Alexandre Santos. GOMES, Janaína Dantas Germano. FERREIRA, Emilia Juliana. LANGENEGGER, Natalia. BISPO, Nikolay Henrique; PESSOA, Olivia Alves Gomes. Desburocratização dos cartórios judiciais: análise dos juizados especiais do tribunal de justiça de são Paulo. Relatório de Pesquisa Instituto de Pesquisa Econômica Aplicada - ipea Brasília, 2015

MELLIM FILHO, Oscar; TRINDADE, Edi Aparecido, (orgs). Acesso à Justiça. Campinas, São Paulo: Editora Alínea, 2012.

MERRY, Sally Engle (2006). Transnational Human Rights and Local Activism: Mapping the Middle, American Anthropologist, 108(1): 38-51. Disponível em http://www.law.berkeley.edu/files/csls/Merry_AA_Transnational_Human_Rights_2006.pd f

MIRANDA, Ana Paula Mendes de. Fisco e cartórios: exemplos de burocracia à brasileira. In: SOUZA LIMA, Antonio Carlos de (org.). Antropologia e Direito, temas antropológicos para estudos jurídicos. Brasília: Ed. Contracapa, 2012.

NIZET, Jean; RIGAUX, Natalie. A sociologia de Erving Goffman. Rio de Janeiro: Editora Vozes, 2016.

NOGUEIRA, Eliane Garcia. Sistema de gestão de unidade judicial. Dissertação (Mestrado Profissional em Poder Judiciário) Escola de Direito, FGV, Rio de Janeiro, 2010. 
NORONHA, Rodolfo. Dentro do Tribunal, fora do processo: análise empírica de novas políticas judiciais. Comunicação apresentada em IX ENCONTRO DA ABCP Brasília, DF 04 a 07 de agosto de 2014.

OLIVEIRA, Fabiana Luci de (org.) Justiça em foco: estudos empíricos Rio de Janeiro: Editora FGV, 2012.

OLIVEIRA, Luis Roberto Cardoso de. A dimensão simbólica dos direitos e a análise de conflitos. Revista de Antropologia, São Paulo, USP, 2010, v. 53 no 2. p. 451-473.

OLIVEIRA, Roberto Cardoso. O trabalho do antropólogo. São Paulo: Editora UNESP,2000.

ORDEM DOS ADVOGADOS DO BRASIL, SUBSEÇÃO SÃO PAULO. OAB ingressa em ADIN para questionar a redução do horário dos fóruns paulistas. Disponível em: http://www.oabsp.org.br/noticias/2013/06/24/8830/. Acesso em 18 de abril de 2014 [10]

PANZARELLA, Robert; SHAPIRO, Irving. Policy, job practices, and personal values in decisionmaking by court officers. Journal of Criminal Justice. Volume 16, Issue 2, pp. 89$165,1988$.

PEIRANO, Mariza (org). A favor da etnografia. Rio de Janeiro : Relume-Dumará, 1995.

. Rituais Ontem e Hoje. São Paulo: Zahar Editora, 2002. 
O dito e o feito: ensaios de antropologia dos rituais. Rio de Janeiro : Relume

Dumará, núcleo de Antropologia da Política/UFRJ, 2002

. Etnografia não é método. Revista Horizontes Antropológicos, n. 42, 2014

PEREIRA, Patrícia Valéria Alkimin. Uma contribuição ao estudo das emoções no trabalho: o caso dos oficiais de justiça avaliadores do juciciário mineiro. Dissertação (Mestrado) Saúde Pública.. Faculdade de Medicina da UFMG. Belo Horizonte 2005

PINTO, danilo. A burocracia vista do cartório. UFSCAR: 2007.

POOLE, Deborah. DAS, veena. El estado y sus márgenes. Etnografías comparadas Cuadernos de Antropología Social No 27, pp. 19-52, 2008 C FFyL - UBA - ISSN: $0327-$ 3776.

RIBEIRO, Ludmila. A Emenda Constitucional 45 e a questão do acesso à justiça. Rev. direito GV. São Paulo, v. 4, n. 2, p. 465-491, Dec. 2008. Disponível em $<$ http://www.scielo.br/scielo.php?script=sci_arttext\&pid=S1808-

24322008000200006\&lng=en\&nrm=iso>. Accesso em 12 Jan. 2017. http://dx.doi.org/10.1590/S1808-24322008000200006.

RUSSO, Andréa Rezende. Uma moderna Gestão de Pessoas no Poder Judiciário. Dissertação (Mestrado Profissional em Poder Judiciário) Escola de Direito, FGV, Rio de Janeiro, 2009.

SADEK, Maria Tereza. SADEK, Maria Tereza. Corpo e alma da magistratura brasileira. Rev. bras. Ci. Soc., São Paulo, v. 13, n. 38,Oct.1998. Disponível em: http://dx.doi.org/10.1590/S0102-69091998000300011. Acesso em setembro de 2012. 
O sistema de justiça. In SADEK, MT. (org.). O sistema de justiça [online]. Rio de Janeiro: Centro Edelstein de Pesquisas Sociais, 2010. pp. 1-23. Disponível em SciELO Books $<$ http://books.scielo.org $>$.

SADEK, Maria Tereza. ARANTES, Rogério Bastos. A crise do Judiciário e a visão dos juízes. Revista USP, n 21, 1994.

SADEK, M. T. ; BENETI, S. A. ; FALCAO, J. ; COLLACO, R. Magistrados - uma imagem em movimento. Rio de Janeiro: Editora FGV, 2006.

SANTOS, André Filipe Pereira Reid dos. Uma introdução à Sociologia das profissões jurídicas. Prisma Jurídico, vol. 11, núm. 1, enero-junio, 2012, pp. 79-99. Universidade Nove de Julho São Paulo, Brasil

SANTOS, Franklin Vieira dos. O Magistrado e o adoecimento no trabalho: aspectos jurídicos e psicológicos. Dissertação (Mestrado Profissional em Poder Judiciário) Escola de Direito, FGV, Rio de Janeiro, 2009.

SAUERBRONN, Fernanda Filgueiras; SAUERBRONN, João Felipe Rammelt. Representações sociais da reforma do Judiciário - um estudo baseado nas perspectivas dos servidores do Tribunal de Justiça do Estado da Bahia. Rev. Adm. Pública - Rio de Janeiro 49(3):719-737, maio/jun. 2015 . DOI: http://dx.doi.org/10.1590/0034-7612130108 
SCHRITZMEYER, Ana Lúcia. Afetos em jogo no tribunal do Júri. Disponível em: http://www.seade.gov.br/produtos/spp/v21n02/v21n02_06.pdf. p. 73 acessado em 15 de fevereiro de 2012.

SCHRITZMEYER, Ana Lúcia P. Jogo, ritual e teatro: um estudo antropológico do Tribunal do Júri. São Paulo: Terceiro Nome, 2012.

SCHUCH, Patrice. Antropologia do Direito: Trajetória e Desafios contemporâneos. São Paulo: Revista BIB, $n^{\text {o }}$ 67, $1^{\mathrm{o}}$ semestre de 2009, pp. 51-73

SENA, Gabriel Astoni; SILVA, Edson Arlindo; LUQUINI, Roberto de Almeida A reforma do Poder Judiciário no Brasil: uma análise a partir do modelo gerencial. Revista de Ciências da Administração v. 14, n. 33, p. 68-78, ago 2012.

SILVA, M.. Produtividade dos juízes federais: em busca de critérios para a definição de um sistema de avaliação. Revista CEJ, América do Norte, 102003 2006. Disponível em http://www.jf.jus.br/ojs2/index.php/revcej/article/view/698/878

SINHORETTO, Jacqueline. Corpos do poder: operadores jurídicos na periferia de São Paulo. UFRGS, Porto Alegre: Sociologias, 2005, v. 13, p. 136-161

SOUZA, Jacqueline de. O Acesso à Justiça no Brasil: Um mapa da Produção Científica Nacional. UNB: Brasília, 2013.

SOUSA SANTOS, Boaventura de. LEITÃO MARQUES, Maria Manuel. PEDROSO, João. Os tribunais nas sociedades contemporâneas. Disponível em 
http://www.anpocs.org.br/portal/publicacoes/rbcs_00_30/rbcs30_07.htm . Rev. bras. Ci. Soc. v.11 n.30 São Paulo fev. 1996. Acessado em 05 de janeiro de 2012.

SILVA, Paulo Eduardo Alves da. Condução planejada de processos judiciais - uma nova racionalidade do exercício jurisdicional entre o tempo e a forma do processo. São Paulo, 2006. Tese (Doutorado em Direito). Faculdade de Direito da Universidade de São Paulo.

SILVA, Vagner Gonçalves da. O Antropólogo e sua magia. São Paulo: Editora Universidade de São Paulo, 2000.

STRATHERN, Marilyn. O efeito Etnográfico. São Paulo: Cosac Naify, 2014.

STRAUSS, Anselm. Espelhos e máscaras. São Paulo: Editora da Universidade de São Paulo, 1999.

SUPIOT, Alain. Homo juridicus: ensaio sobre a função antropológica do direito. São Paulo: WMF Martins Fontes, 2007.

TAVARES, D. S. O sofrimento no trabalho entre servidores públicos: uma análise psicossocial do contexto de trabalho de um Tribunal Judiciário Federal. 2003. Dissertação (Mestrado em Saúde Ambiental) - Faculdade de Saúde Pública, Universidade de São Paulo, São Paulo, 2003. Disponível em: <www.teses.usp.br/teses/disponiveis/6/6134/tde20032004-083408/>. Acesso em: 07 mai. 2014.

TRIBUNAL DE JUSTIÇA DO ESTADO DE SÃO PAULO. Regulamento Interno do Tribunal de Justiça. 
VARELLA, Santiago. Percepções dos servidores sobre os desafios da gestão do Poder Judiciário Série temática do Censo do Poder Judiciário - No 1 . CONSELHO NACIONAL DE JUSTIÇA. 2013

VILLARDI, Beatriz Quiroz, FERRAZ, Viviane Narducci, DUBEUX. Veranise Jacubowski Correia. Uma metodologia para diagnóstico de clima organizacional: integrando motivos sociais e cultura brasileira com fatores do ambiente de trabalho do Poder Judiciário. Fundação Getulio Vargas, RAP — RIO DE JANEIRO 45(2):303-29, MAR./ABR. 2011

VINUTO, Juliana. Representações sociais sobre a família do adolescente em confito com a lei: a lei e suas ressignifcações. Cadernos de campo, São Paulo, n. 22, p. 325-335, 2013.

WEBER, M. Economia e sociedade. Brasília: Imprensa Oficial/ Universidade de Brasília, v. 1, 1999.

VIANNA, Luiz Werneck et al. Corpo e alma da magistratura brasileira. Rio de Janeiro: Editora Revan, 1997. 


\title{
ANEXOS
}

ANEXO I Lista de prédios administrativos e fóruns da cidade de São Paulo segundo o site do Tribunal de Justiça, em dezembro de 2016.

\author{
Almoxarifado Geral \\ Anexo do Juizado Especial Cível da Lapa (UMC) \\ Centro Administrativo - Consolação \\ Centro de Integração da Cidadania - CIC Feitiço da Vila \\ Centro de Integração da Cidadania - CIC Leste \\ Centro de Integração da Cidadania - CIC Norte \\ Centro de Integração da Cidadania - CIC Oeste \\ Centro de Integração da Cidadania - CIC SUL \\ Complexo Judiciário "Ministro Mário Guimarães" \\ Complexo Judiciário Ipiranga \\ Foro Regional II - Santo Amaro - (03 prédios) \\ Foro Regional III - Jabaquara/Saúde \\ Foro Regional XV - Butantã \\ Fórum Brás (Varas Especiais da Infância e Juventude) \\ Fórum Itaquera-Guaianases - (JEC/CEJUSC) \\ Fórum João Mendes Júnior \\ Fórum Regional IV Lapa (I e II) \\ Fórum Nossa Senhora do Ó \\ Fórum Ipiranga \\ Fórum Regional VI - Penha de França - (Danylo José Fernandes) \\ Fórum Regional XI - Pinheiros \\ Fórum Santana \\ Fórum São Miguel Paulista \\ Fórum Tatuapé \\ Fórum Vila Prudente \\ Fórum das Execuções Fiscais da Fazenda Pública - 35 \\ Fórum das Execuções Fiscais da Fazenda Pública - 72 \\ Fórum do Juizado Especial Cível Central - I \\ Fórum do Juizado Especial Cível Central - II
}


Fórum do Juizado Especial Digital (Expressinho Digital)

Fórum Hely Lopes Meirelles - (Fazenda Pública/Acidentes)

Fórum Regional VII - Itaquera

Prédio Administrativo Brigadeiro Luis Antônio

Prédio Administrativo Conde do Pinhal

Prédio Administrativo Psicossocial - Tabatinguera

Prédio do CEJUSC CENTRAL (Barra Funda)

Prédio Pedro Lessa

Tribunal de Justiça - GADE 23 de Maio

Tribunal de Justiça - GADE 9 de Julho

Tribunal de Justiça - GADE I (Conselheiro Furtado.669)

Tribunal de Justiça - GADE I (Conselheiro Furtado.705)

Tribunal de Justiça - GADE II (Conselheiro Furtado.688)

Tribunal de Justiça - MMDC

Tribunal de Justiça - Palácio da Justiça

Tribunal de Justiça - Pátio do Colégio

Tribunal de Justiça (Provisório)

Prédio da Praça do Patriarca

Bela Cintra - SAS - Secretaria da Área da Saúde

Prédio da Rua Conselheiro Furtado 503/511

Prédio da Tabatinguera 164 


\title{
ANEXO II Normativas que tratam especificamente do acesso de advogados e advogadas aos fóruns e processos:
}

\section{Normas da Corregedoria do Tribunal de Justiça do estado de São Paulo:}

\author{
Da Consulta e da Carga dos Autos
}

\begin{abstract}
Art. 157. O acesso aos autos judiciais e administrativos de processos em andamento ou findos, mesmo sem procuração, quando não estejam sujeitos a segredo de justiça, é assegurado aos advogados, estagiários de Direito e ao público em geral, por meio do exame em balcão do ofício de justiça ou seção administrativa, podendo ser tomados apontamentos, solicitadas cópias reprográficas, bem como utilizado escâner portátil ou máquina fotográfica, vedado, nestas hipóteses, o desencarte das peças processuais para reprodução.
\end{abstract}

Parágrafo único. Os escrivães judiciais e os chefes de seção judiciária manterão, pessoalmente ou mediante servidor designado, rigorosa vigilância sobre os autos dos processos, sobretudo quando do seu exame, por qualquer pessoa, no balcão do ofício de justiça ou seção administrativa.

Art. 158. Para garantia do direito de acesso aos autos que não corram em segredo de justiça, poderão os advogados ou estagiários de Direito, regularmente inscritos na $\mathrm{OAB}$, que não tenham sido constituídos procuradores de quaisquer das partes, retirar os autos para cópia, pelo período de 1 (uma) hora, mediante controle de movimentação física, devendo o serventuário consultar ao sítio da Ordem dos Advogados do Brasil da Internet, à vista da Carteira da $\mathrm{OAB}$ apresentada pelo advogado ou estagiário de Direito interessado, com impressão dos dados obtidos, os quais serão conferidos pelo servidor antes da entrega dos autos, observadas, ainda, as demais cautelas previstas para a carga rápida, conforme o disposto no art. 165.5

Art. 159. Nos casos complexos ou com pluralidade de interesses, a fim de que não seja prejudicado nem o andamento do feito e nem o acesso aos autos, fica autorizada a retirada de cópias de todo o feito, que ficarão à disposição para consulta dos interessados.

Art. 160. Na hipótese de os processos correrem em segredo de justiça, o seu exame, em cartório, será restrito às partes e a seus procuradores devidamente constituídos. 
$\S 1^{\circ}$ As entidades que reconhecidamente prestam serviços de assistência judiciária poderão, por intermédio de advogado com procuração nos autos, autorizar a consulta de processos que tramitam em segredo de justiça em cartório pelos acadêmicos de Direito não inscritos na $\mathrm{OAB}$. Referida autorização deverá conter o nome do acadêmico, o número de seu RG e o número e/ou nome das partes do processo a que se refere a autorização, que será juntada posteriormente aos autos.

$\S 2^{\circ}$ É vedado o acesso a autos de processos que correm em segredo de justiça por estagiários não inscritos ou com inscrição vencida na $\mathrm{OAB}$.

Art. 161. A carga de autos judiciais e administrativos em andamento no cartório é reservada unicamente a advogados ou estagiários de Direito regularmente inscritos na $\mathrm{OAB}$, constituídos procuradores de alguma das partes, ressalvado, nos processos findos e que não estejam sujeitos a segredo de justiça, a carga por advogado mesmo sem procuração, pelo prazo de 10 (dez) dias. 2

Art. 162. O escrivão ou o escrevente responsável pelo atendimento registrará a retirada e a devolução de autos, mediante anotação no sistema informatizado oficial e no relatório de carga emitido pelo sistema (carga eletrônica), observadas as seguintes cautelas: I - na retirada dos autos, o advogado ou estagiário de Direito lançará sua assinatura no relatório de carga emitido pelo sistema informatizado, arquivando-se o documento provisoriamente em classificador próprio; II - na devolução do feito, o servidor do ofício de justiça ou da seção administrativa efetuará a baixa no relatório de carga, juntando-o imediatamente aos autos.

$\S 1^{\circ} \mathrm{O}$ livro de carga de autos para advogados será utilizado quando não for possível a utilização do sistema informatizado, caso em que serão lançados, no livro, a assinatura do destinatário e, nos autos, o termo de carga e recebimento.

$\S 2^{\circ}$ No relatório eletrônico ou no livro de carga constarão o número da carteira profissional e respectiva seção, expedida pela $\mathrm{OAB}$, em nome do destinatário, facultado ao servidor, na dúvida, solicitar sua exibição. $\S 3^{\circ} \mathrm{A}$ baixa da carga de autos, constante de relatório eletrônico ou de livro de carga, far-se-á imediatamente, à vista do interessado, sendo-lhe facultada a obtenção de recibo de autos, assinado pelo servidor, em instrumento previamente confeccionado pelo interessado e do qual constarão designação da ofício de justiça ou da seção administrativa, número do processo, tipo de demanda, nome das partes e data da devolução. A cada auto processual corresponderá um recibo e a subscrição pelo servidor não implica reconhecimento da respectiva regularidade interna. $\S 4^{\circ} \mathrm{O}$ procedimento previsto neste artigo poderá ser aplicado a 
outras modalidades de cargas, desde que disponível a funcionalidade (carga eletrônica) no sistema informatizado para outros destinatários e o método se revele eficiente.

Art. 163. Os representantes judiciais da Fazenda Pública e os membros do Ministério Público e da Defensoria Pública, mediante petição dirigida ao Juiz Corregedor Permanente, poderão indicar funcionários ou estagiários autorizados a retirarem, em nome daqueles, os autos em carga. $\S 1^{\circ}$ Da petição, que será arquivada em pasta própria, constarão os nomes completos, os números dos documentos de identidade, do CPF e os números das identificações funcionais, se o caso. $\S 2^{\circ} \mathrm{O}$ funcionário ou estagiário deverá portar o documento de identidade e a cédula ou crachá funcional, conforme o caso, no momento da retirada dos autos, para que o ofício de justiça possa verificar, mediante conferência das petições arquivadas, se a pessoa encontra-se autorizada a subscrever a carga. $\S 3^{\circ} \mathrm{A}$ carga dos autos será feita em nome da pessoa que subscreveu a autorização e dela constarão os dados da pessoa que estiver retirando os autos. 1 Prov. CGJ 23/2003. 2 Prov. CGJ 09/2011. § $4^{\circ}$ Qualquer alteração no rol de pessoas autorizadas a retirar os autos deverá ser imediatamente comunicada ao Juiz Corregedor Permanente.

Art. 164. Não havendo fluência de prazo, os autos somente serão retirados em carga mediante requerimento.

$\S 1^{\circ}$ Na fluência de prazo, os autos não sairão do ofício de justiça, salvo nas hipóteses expressamente previstas na legislação vigente, ressalvado, porém, em seu curso ou em outras hipóteses de impossibilidade de retirada dos autos, o direito de requisição de cópias quando houver justificada urgência na extração respectiva, mediante autorização judicial, observando-se o procedimento próprio.

$\S 2^{\circ} \mathrm{Na}$ fluência de prazo comum, só em conjunto ou mediante prévio ajuste por petição nos autos, os procuradores das partes retirarão os autos, ressalvada a obtenção de cópias para a qual cada procurador poderá retirá-los pelo prazo de 2 (duas) a 6 (seis) horas, mediante carga rápida, independentemente de ajuste, observado o término do expediente forense. 2

Art. 165. A carga rápida dos autos será concedida pelo escrivão ou o escrevente responsável pelo atendimento, pelo período de uma hora, mediante controle de movimentação física dos autos, conforme formulário a ser preenchido e assinado por advogado ou estagiário de Direito devidamente constituído no processo, respeitado o seguinte procedimento: I - os requerimentos serão recepcionados e atendidos desde que formulados até às $18 \mathrm{~h} ; 3$ II - o formulário de controle de movimentação física será juntado aos autos no exato momento de sua devolução ao ofício de justiça, certificandose o respectivo período de vista; 4 III - na hipótese dos autos não serem restituídos no 
período fixado, competirá ao escrivão judicial representar, no prazo de 24 (vinte e quatro) horas, ao Juiz Corregedor Permanente, inclusive para fins de providências competentes junto à Ordem dos Advogados do Brasil (EOAB, arts. 34, inciso XXII, e 37 , inciso I). 5

Art. 166. É vedada a retenção do documento de identificação do advogado ou do estagiário de Direito no ofício de justiça, para a finalidade de controle de carga de autos, em qualquer modalidade ou circunstância.

Art. 167. O advogado deve restituir, no prazo legal, os autos que tiver retirado do ofício de justiça. Se intimado, o advogado não devolver os autos no prazo de 3 (três) dias, perderá o direito à vista fora de cartório e incorrerá em multa correspondente à metade do salário mínimo.6 $\S 1^{\circ}$ Verificada a falta, o juiz comunicará o fato à seção local da Ordem dos Advogados do Brasil para procedimento disciplinar e imposição das penalidades. $7 \S 2^{\circ} \mathrm{O}$ expediente de cobrança de autos receberá autuação singela, sem necessidade de registro. $8 \S 3^{\circ}$ Devolvidos os autos, o ofício de justiça, depois de seu minucioso exame, juntará o expediente de cobrança de autos, certificando a data e o nome de quem os retirou e devolveu $\S 4^{\circ} \mathrm{Na}$ hipótese de extravio dos autos, o expediente de cobrança instruirá o respectivo procedimento de restauração. Art.

168. O escrivão ou o chefe de seção deverá, mensalmente, até o décimo dia útil do mês subsequente, verificar o cumprimento dos prazos de devolução dos autos retirados, relacionar, em duas vias, os autos em poder das partes além dos prazos legais ou fixados, a primeira encaminhada, sob forma de representação, ao Juiz Corregedor Permanente, para as providências previstas no art. 167 e a segunda via, para acompanhamento e controle, arquivada em pasta própria.

Art. 169. O disposto nesta seção aplica-se, no que couber, a todos os demais destinatários de carga.

\section{Código de Processo Civil de 2015:}

Art. 107. O advogado tem direito a:

I - examinar, em cartório de fórum e secretaria de tribunal, mesmo sem procuração, autos de qualquer processo, independentemente da fase de tramitação, assegurados a obtenção de cópias e o registro de anotações, salvo na hipótese de segredo de justiça, nas quais apenas o advogado constituído terá acesso aos autos; 
II - requerer, como procurador, vista dos autos de qualquer processo, pelo prazo de 5 (cinco) dias;

III - retirar os autos do cartório ou da secretaria, pelo prazo legal, sempre que neles lhe couber falar por determinação do juiz, nos casos previstos em lei.

$\S 1^{\circ}$ Ao receber os autos, o advogado assinará carga em livro ou documento próprio.

$\S 2^{\circ}$ Sendo o prazo comum às partes, os procuradores poderão retirar os autos somente em conjunto ou mediante prévio ajuste, por petição nos autos.

$\S 3^{\circ}$ Na hipótese do $\S 2^{\circ}$, é lícito ao procurador retirar os autos para obtenção de cópias, pelo prazo de 2 (duas) a 6 (seis) horas, independentemente de ajuste e sem prejuízo da continuidade do prazo.

$\S 4^{\circ} \mathrm{O}$ procurador perderá no mesmo processo o direito a que se refere o $\S 3^{\circ}$ se não devolver os autos tempestivamente, salvo se o prazo for prorrogado pelo juiz.

\section{Lei 8906 de 1994 - Estatuto da Advocacia:}

\section{CAPÍTULO II}

Dos Direitos do Advogado

Art. $6^{\circ}$ Não há hierarquia nem subordinação entre advogados, magistrados e membros do Ministério Público, devendo todos tratar-se com consideração e respeito recíprocos. Parágrafo único. As autoridades, os servidores públicos e os serventuários da justiça devem dispensar ao advogado, no exercício da profissão, tratamento compatível com a dignidade da advocacia e condições adequadas a seu desempenho.

Art. $7^{\circ}$ São direitos do advogado:

(...)

VI - ingressar livremente:

a) nas salas de sessões dos tribunais, mesmo além dos cancelos que separam a parte reservada aos magistrados;

b) nas salas e dependências de audiências, secretarias, cartórios, ofícios de justiça, serviços notariais e de registro, e, no caso de delegacias e prisões, mesmo fora da hora de expediente e independentemente da presença de seus titulares;

c) em qualquer edifício ou recinto em que funcione repartição judicial ou outro serviço público onde o advogado deva praticar ato ou colher prova ou informação útil ao exercício da atividade profissional, dentro do expediente ou fora dele, e ser atendido, desde que se ache presente qualquer servidor ou empregado;

d) em qualquer assembléia ou reunião de que participe ou possa participar o seu cliente, ou perante a qual este deva comparecer, desde que munido de poderes especiais;

VII - permanecer sentado ou em pé e retirar-se de quaisquer locais indicados no inciso anterior, independentemente de licença; 
VIII - dirigir-se diretamente aos magistrados nas salas e gabinetes de trabalho, independentemente de horário previamente marcado ou outra condição, observando-se a ordem de chegada;

IX - sustentar oralmente as razões de qualquer recurso ou processo, nas sessões de julgamento, após o voto do relator, em instância judicial ou administrativa, pelo prazo de quinze minutos, salvo se prazo maior for concedido;

$\mathrm{X}$ - usar da palavra, pela ordem, em qualquer juízo ou tribunal, mediante intervenção sumária, para esclarecer equívoco ou dúvida surgida em relação a fatos, documentos ou afirmações que influam no julgamento, bem como para replicar acusação ou censura que lhe forem feitas;

XI - reclamar, verbalmente ou por escrito, perante qualquer juízo, tribunal ou autoridade, contra a inobservância de preceito de lei, regulamento ou regimento;

XII - falar, sentado ou em pé, em juízo, tribunal ou órgão de deliberação coletiva da Administração Pública ou do Poder Legislativo;

XIII - examinar, em qualquer órgão dos Poderes Judiciário e Legislativo, ou da Administração Pública em geral, autos de processos findos ou em andamento, mesmo sem procuração, quando não estejam sujeitos a sigilo, assegurada a obtenção de cópias, podendo tomar apontamentos;

(...)

$\mathrm{XV}$ - ter vista dos processos judiciais ou administrativos de qualquer natureza, em cartório ou na repartição competente, ou retirá-los pelos prazos legais;

XVI - retirar autos de processos findos, mesmo sem procuração, pelo prazo de dez dias; (...)

XX - retirar-se do recinto onde se encontre aguardando pregão para ato judicial, após trinta minutos do horário designado e ao qual ainda não tenha comparecido a autoridade que deva presidir a ele, mediante comunicação protocolizada em juízo.

(...)

\section{$\S 1^{\circ}$ Não se aplica o disposto nos incisos XV e XVI:}

1) aos processos sob regime de segredo de justiça;

2) quando existirem nos autos documentos originais de difícil restauração ou ocorrer circunstância relevante que justifique a permanência dos autos no cartório, secretaria ou repartição, reconhecida pela autoridade em despacho motivado, proferido de ofício, mediante representação ou a requerimento da parte interessada;

3) até o encerramento do processo, ao advogado que houver deixado de devolver os respectivos autos no prazo legal, e só o fizer depois de intimado.

$\S 2^{\circ} \mathrm{O}$ advogado tem imunidade profissional, não constituindo injúria, difamação ou desacato puníveis qualquer manifestação de sua parte, no exercício de sua atividade, em juízo ou fora dele, sem prejuízo das sanções disciplinares perante a OAB, pelos excessos que cometer. 
(...)

$\S 10$. Nos autos sujeitos a sigilo, deve o advogado apresentar procuração para o exercício dos direitos de que trata o inciso XIV.

$\S 11$. No caso previsto no inciso XIV, a autoridade competente poderá delimitar o acesso do advogado aos elementos de prova relacionados a diligências em andamento e ainda não documentados nos autos, quando houver risco de comprometimento da eficiência, da eficácia ou da finalidade das diligências.

$\S$ 12. A inobservância aos direitos estabelecidos no inciso XIV, o fornecimento incompleto de autos ou o fornecimento de autos em que houve a retirada de peças já incluídas no caderno investigativo implicará responsabilização criminal e funcional por abuso de autoridade do responsável que impedir o acesso do advogado com o intuito de prejudicar o exercício da defesa, sem prejuízo do direito subjetivo do advogado de requerer acesso aos autos ao juiz competente. (Incluído pela Lei no 13.245, de 2016) Art. $7^{\circ}$-A. São direitos da advogada:

I - gestante:

a) entrada em tribunais sem ser submetida a detectores de metais e aparelhos de raios $\mathrm{X}$;

b) reserva de vaga em garagens dos fóruns dos tribunais; 